Volume 12

Issue 2 Images And Collective Violence:

Function, Use And Memory

Article 6

$10-2018$

\title{
Bonding Images: Photography and Film as Acts of Perpetration
}

Christophe Busch

Kazerne Dossin: Memorial, Museum and Research Center

Follow this and additional works at: https://digitalcommons.usf.edu/gsp

\section{Recommended Citation}

Busch, Christophe (2018) "Bonding Images: Photography and Film as Acts of Perpetration," Genocide Studies and Prevention: An International Journal: Vol. 12: Iss. 2: 54-83.

DOI:

https://doi.org/10.5038/1911-9933.12.2.1526

Available at: https://digitalcommons.usf.edu/gsp/vol12/iss2/6

This Articles is brought to you for free and open access by the Open Access Journals at Digital Commons @ University of South Florida. It has been accepted for inclusion in Genocide Studies and Prevention: An International Journal by an authorized editor of Digital Commons @ University of South Florida. For more information, please contact digitalcommons@usf.edu. 


\title{
Bonding Images: Photography and Film as Acts of Perpetration
}

\author{
Christophe Busch \\ Kazerne Dossin: Memorial, Museum and Research Center \\ Mechelen, Belgium
}

\section{"Schöne Zeiten"}

On December 2, 1959, SS-Untersturmführer (second lieutenant) Kurt Franz was arrested at his home in Düsseldorf. As a former cook, he joined the Waffen-SS in 1937 (Third SS-Totenkopfstandarte Thuringia) and worked at the Buchenwald concentration camp near Weimar. At the start of the Second World War, he was summoned to the Führer's chancellery and was asked to serve as kitchen chief at Grafeneck, Hartheim, Brandenburg and Sonnenstein. At these psychiatric institutions, the T4 euthanasia program, which included the killing of psychiatrically ill people in Germany and Austria, was executed. In late 1941, Franz was stationed at the headquarters of the euthanasia program at Tiergartenstrasse 4 (T4) in Berlin from where this murderous program was planned and ordered. ${ }^{1}$ Together with several other T4 colleagues, he was transferred to the Belzec extermination camp in the spring of 1942 and to Treblinka in midsummer that year. There the former cook rose to become the deputy of camp commander Franz Stangl and finally became the last camp commander of Treblinka from August until November 1943. Until the end of the war, Franz was deployed in Trieste and northern Italy and engaged in the persecution of partisans and Jews. After the war, he worked until 1949 as a construction worker on bridges and later became a cook again in Düsseldorf just until his arrest. Five years later (1965), he was sentenced to life imprisonment for his criminal actions in Treblinka. ${ }^{2}$ The Landesgericht in Düsseldorf stated "he ill-treated, punched, beat and killed when it gave him pleasure and when he felt like it. Did not bother him in the least when his St. Bernard dog Barry leapt at helpless Jews at his bidding ... and wounded and tore them to pieces in his presence ... A large part of the streams of blood and tears that flowed in Treblinka can be attributed to him alone." ${ }^{3}$ Franz often incited his dog against the prisoners with the words "Man, grab the dog!" The verdict of the Treblinka tribunal clarifies that with the word "man", he referred to Barry and that the word "dog" referred to the prisoner. Franz was released in 1993 due to health reasons and finally died in 1998 in a home for the elderly in Wuppertal.

Aside from his remarkable pathway from Buchenwald through the T4 institutions to the extermination camps and his incremental career steps from cook/guard to (deputy) camp commander, Franz has also left us an intriguing time document. During his arrest in 1959, the investigators discovered a photo album with snapshots taken in the Treblinka extermination camp and of his activities later in Italy. ${ }^{4}$ The album had the inscription "Schöne Zeiten" (Beautiful Years) on the first page and was a carefully made visual memory of the highlights of his military service. ${ }^{5}$ It showed photos of him together with the camp commander Franz Stangl at the door of the commandants' barracks at Treblinka, his dog Barry at the zoo, the construction of the extermination camp Treblinka ${ }^{6}$, him posing with his brother who worked as a Luftwaffe soldier and several other memories in Italy during the last years of the war. ${ }^{7}$ After the war, the word "Schöne" was erased (but still readable), and two photos on the bottom-left and bottom-right areas of the page were torn out. It is left to researchers' imaginations what these two photos could have shown, but the erased word and the missing photos share a story on their own. It is clear that for Franz the context after 1945 dramatically changed. What was once proof of the most "beautiful years" of his life could now

\footnotetext{
${ }^{1}$ Sara Berger, Experten der Vernichtung: das T4-Reinhardt-Netzwerk in den Lagern Belzec, Sobibor und Treblinka (Hamburg: Hamburger Edition, 2014), 45.

${ }^{2}$ Ibid., 404.

${ }^{3}$ Ernst Klee, et al. The good old days: the Holocaust as seen by its perpetrators and bystanders (Old Saybrook, CT: Konecky \& Konecky, 2005), 291-292.

${ }^{4}$ Volker Rieß, "20 Jahre nach 'Schöne Zeiten.' Ein kritischer Rückblick mit Bildern," Mitteilungen aus dem Bundesarchiv (2008), accessed May 1, 2017, https://www.bundesarchiv.de/fachinformationen/01816/index.html.de.

${ }^{5}$ Klee, The good old days, 225-227.

${ }^{6}$ Berger, Experten der Vernichtung, 205-212.

${ }^{7}$ Clément Chéroux, Mémoire des camps: photographies des camps de concentration et d'extermination nazis (1933-1999) (Paris: Marval, 2001), 76-77.
}

Christophe Busch. "'Bonding Images: Photography and Film as Acts of Perpetration" Genocide Studies and Prevention 12, 2 (2018): 54-83. 02018 Genocide Studies and Prevention. 
be seen as possible proof of involvement in the Nazi extermination policy, but the album never lost its authentic meaning to Franz as a private family album that was carefully made and kept all these years. In the after-war period, he chose not to get rid of the album but only to mildly intervene and delete the photos and text fragments that were possibly incriminating and provocative. Even though the remaining photos were still undeniable proof of his involvement, he chose to cherish this visual reminder of his successful career.
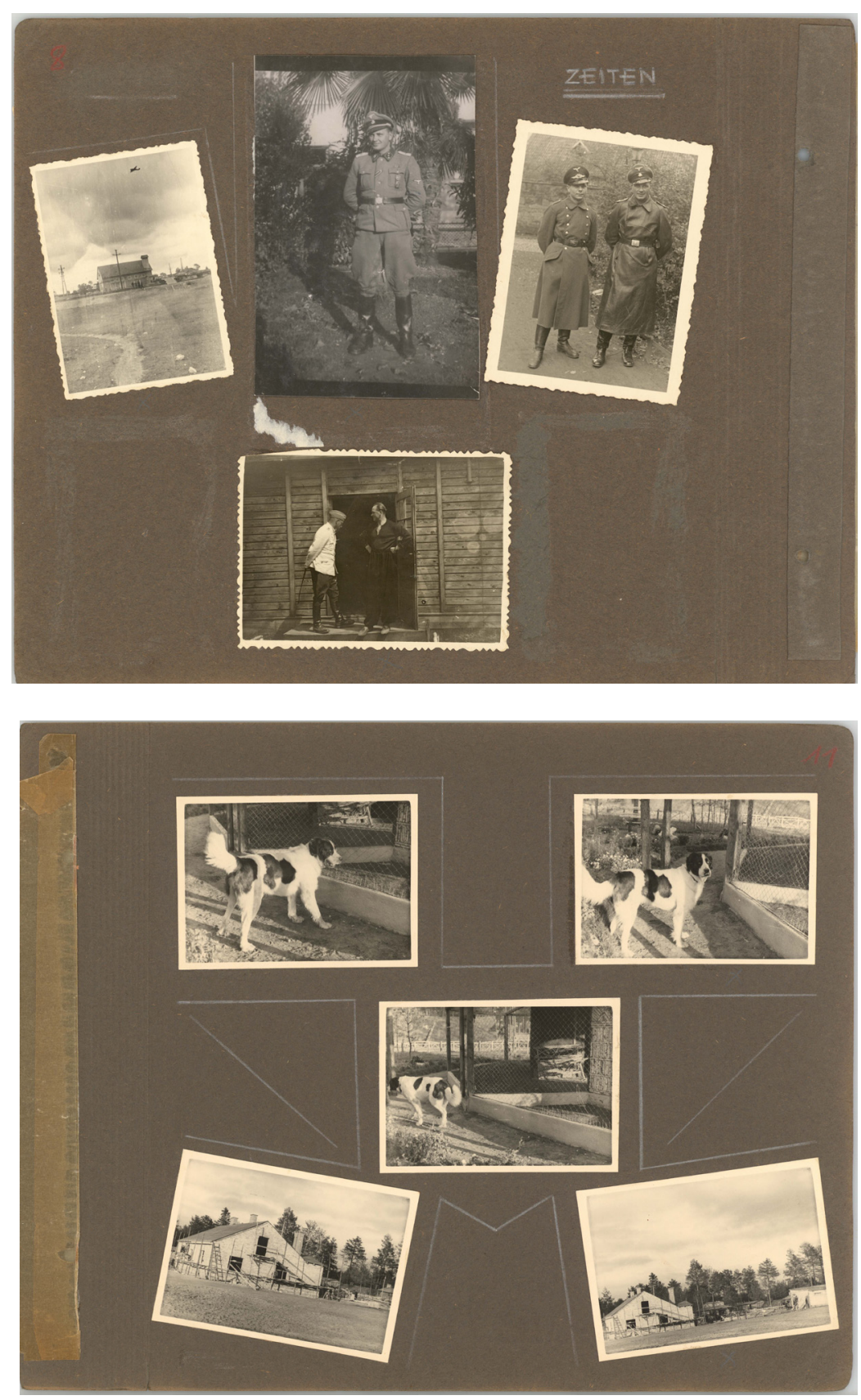

Two pages from the Kurt Franz photo album. On the first page of the album, two photos were torn out, and the inscription "Schöne" was erased, most likely after the war. The album was discovered by police investigators after the arrest of Kurt Franz at his home in Dusseldorf. ${ }^{8}$

8 “Abteilung Rheinland," n.d., Landesarchiv NRW collection, RWB 18244a_0008 and RWB 18244a_0011. 


\section{Perpetrator Photography}

The Franz album and similar collections, such as the Karl Höcker album from Auschwitz, can be seen as visual sources that shed some light on the perpetrators' networks and their framework of reference. ${ }^{9}$ Their world is often a parallel one that we barely know and also prefer to place outside our world of conscience. Evilness is more likely to be seen as a characteristic of the others, something that is exclusively preserved for them, i.e. the Nazis, the collaborators and the perpetrators. When the public at large is (visually) confronted with some of the everyday aspects of this perpetrator world, they usually examine and evaluate it as proof of their inhumanness and perversity. Camaraderie, social activities and other signs of bonding in such spaces of cruelty are seen as evidence of their psycho-pathological make-up or other malicious character elements. In spite of this understandable viewpoint related to our empathic and compassionate feelings towards the victim group, the mad or bad hypothesis, which reduces perpetrator behavior as a dispositional characteristic of madness or evilness, rarely appears to be the case. ${ }^{10}$ Of course we wonder how it was humanly possible to commit these atrocities and even more how and why they were able to photograph suchlike events and situations. However, due to problems of positionality, these visual perpetrator sources are mostly unseen or misinterpreted. We rarely analyze this imagery on the multitude of meanings or functions they can have, considering the limitations of studying these sources. An in-depth analysis of these camp albums and other atrocity imagery can help us in understanding how the perpetrators reflected upon the world, how they positioned themselves in it and how it shaped their respective behavior. ${ }^{11}$ In doing so, we realize that making family albums is what human beings have done since the inception of photography. Susan Sontag stated "through photographs, each family constructs a portrait chronicle of itself - a portable kit of images that bears witness to its connectedness. It hardly matters what activities are photographed so long as photographs are taken and cherished."12 Many perpetrators of collective violence took personal or official snapshots during their military service, collecting moments of togetherness and documenting the sometimesviolent spaces in which they operated. ${ }^{13}$ Places such as Belzec, Treblinka, Chelmno, Sobibor, Lublin and Auschwitz resulted in the annihilation of millions of people and represent for us the darkest pages in our human history. Nevertheless, for most of the perpetrators, these places seem to be mere stations in their career pathways and often opportunities for professional advancement. ${ }^{14}$

It is also important to realize that these extermination camps were only the end stage in a process of cumulative radicalization that had started many years earlier. ${ }^{15}$ This gradual process leading to the extermination camps was continuously shaped from top to bottom and vice versa during the 12 years of Nazi power. ${ }^{16}$ This process of cumulative radicalization was intensively documented with a vast amount of imagery showing scenes of racial degradation, humiliation, exclusion, isolation and finally the extermination of specific targeted groups within the Nazi community. These visual traces are not only extensive but also diverse in nature. They are gradually built from personal anti-Semitic carnival photos, over private and official dehumanizing and humiliating photos, towards the imagery of executions in the killing fields and finally the almost industrial murder

\footnotetext{
${ }^{9}$ Christophe Busch, et al, eds., Das Höcker-Album: Auschwitz durch die Linse der SS (Darmstadt: Von Zabern, 2016).

${ }^{10}$ Christophe Busch, “Demonic Transitons: How Ordinary People Can Commit Extraordinary Evil," in Genocide: New perspectives on its causes, courses and consequences, ed. Üngör Ugur Ümit (Amsterdam: Amsterdam University Press, 2016), 49-50.

${ }^{11}$ Michael Wildt, “Die Epochenzäsur 1989/90 und die NS-Historiographie," Zeithistorische Forschungen/Studies in Contemporary History no. 5 (2008), 369-370.

${ }^{12}$ Susan Sontag, On photography (New York: Picador, 2010), 8.

${ }^{13}$ Janina Struk, Photographing the Holocaust: interpretations of the evidence (London: I.B. Tauris, 2011), 66.

${ }^{14}$ Klaus-Michael Mallmann and Gerhard Paul, eds. Karrieren der Gewalt: nationalsozialistische Täterbiographien (Darmstadt: Primus, 2013), 4-5.

${ }^{15}$ Hans Mommsen, "Cumulative radicalisation and progressive self-Destruction as structural determinants of the Nazi dictatorship," in Stalinism and Nazism: Dictatorships in Comparison, eds. Ian Kershaw and Lewin Moshe (Cambridge, UK: Cambridge University Press, 2005), 75-87.

${ }^{16}$ Ian Kershaw, "'Working towards the Führer': reflections on the nature of the Hitler dictatorship," in Stalinism and Nazism: Dictatorships in Comparison, eds. Ian Kershaw and Lewin Moshe (Cambridge, UK: Cambridge University Press, 2005), 88-106.
} 
of hundreds of thousands of victims in the Aktion Reinhard camps. This so-called "processing of numbers or cargo," ${ }^{17}$ where the victims were completely dehumanized and reduced to objects, can be seen in the Auschwitz presentation album that was discovered in 1945 by former prisoner Lili Jacob-Zelmanovic. ${ }^{18}$ In this unique album, each step of the extermination process, except the gassings themselves, was carefully captured and brought together by the SS-Erkennungsdienst (photographic department) in Auschwitz. ${ }^{19}$ It shows the most gruesome pictures of Jewish fathers, mothers, grandparents and children fearfully waiting for their deaths in the woods near the gas chambers at Birkenau. This specific Auschwitz album is the only one that was discovered after the war portraying the arrival of victims, the selections, the Kanada barracks where the stolen goods were collected and processed, the intake process of the small group that was sent to the surrounding labor camps and, of course, the majority of victims that were forced to the gas chambers at Auschwitz-Birkenau. According to Wilhelm Brasse, a Polish prisoner and photographer who worked at the Erkennungsdienst of Auschwitz, 15 of such presentation albums were made for high-ranking officers..$^{20}$ This album shows not only a part of the extermination process but also the ideological lens that the SS handled. All the photos from the SS albums (personal or official) were made through the Nazi ideological viewfinder and focused on the one hand on honor, obedience, camaraderie, cleanliness and so-called superiority of the perpetrators (Übermenschen) and on the other hand on the supposedly subhuman racial characteristics of the victims (Untermenschen). SS-Oberscharführer Walter Bernhard, the head of the Erkennungsdienst in Auschwitz, captured together with his deputy Ernst Hofmann several Jewish disabled people for the Lili Jacob album. ${ }^{21}$ Many Nazi photographers hunted for such scenes for visual proof of the alleged degenerative characteristics of the Jewish race, which confirmed their racial framework of reference that divided Us from Them. ${ }^{22}$

The imagery from the camps displays the final phase of an incremental process of desubjectification, from alleged inferior human beings towards beasts and finally cargo. In analyzing how this ultimate destruction - and capturing it - was humanly possible, we have mainly relied on millions of written documents such as orders, speeches, testimonies, et cetera. Photos and films were often used as an additive in books and exhibitions to visually validate what the words were explaining. However, one can question if that is the only possible and interesting handling of this imagery and if we are not using it almost exclusively as a form of confirmation or projection of what we (think) we already know. This rather simple interpretation often results in the confirmation bias that these pictures and footage are proof of the innate evilness and madness of the perpetrators. Being confronted with photo albums of "Schöne Zeiten," showing camaraderie and other group dynamics, we need to wonder what these visual narratives are really saying. The multitude of functions they can have may help explain, not excuse, perpetrator behavior. One may wonder how to contextualize and interpret this imagery beyond the classical projection of evilness. In addition, researchers undertake the difficult task of determining how to archeologically excavate the different layers of information in these pictures, the motives for photographing and filming the atrocities, the effects of capturing, viewing and sharing such imagery on the broader process of perpetration, the diverse networks and relations and their significant interactions we can distinguish, the behavioral group dynamics at play and all other possible insights that are enclosed in these visual sources. My argument is that the imagery of the Holocaust has gradually shaped a visual framework of

\footnotetext{
${ }^{17}$ I refer to the visit of Fritz Hensel, Rudolf Höss's brother in law, in Auschwitz. Upon asking what the term Untermensch meant, Höss replied: "Look you can see for yourself. They are not like you and me. They are different. They look different. They do not behave like human beings. They have number on their arms. They are here in order to die." Quoted in: Tom Segev, Soldiers of Evil: The Commandants of the Nazi Concentration Camps (New York: McGraw-Hill, 1988), 264.

${ }^{18}$ Israel Gutman and Guterman Belah, The Auschwitz album: The Story of a Transport (Jerusalem: Yad Vashem, 2008), 101274.

${ }^{19}$ Wilhelm Brasse and Maria Anna Potocka, Wilhelm Brasse, Fotograf, 3444, Auschwitz 1940-1945 (Berlin: Revolver Publ. by VVV, 2011), 11-17; Struk, Photographing the Holocaust, 102-116.

${ }^{20}$ Brasse, Wilhelm Brasse, Fotograf, 121. In an interview with Janina Struk, Brasse claimed earlier that at least three such albums were made. Some of them were sent to Berlin. See: Struk, Photographing the Holocaust, 111.

${ }^{21}$ Struk, Photographing the Holocaust, 120.

${ }^{22}$ Ibid., 108.
} 
reference that has effected, among other elements, the process of perpetration. In other words, we need to shift from monocausal or dualistic explanations towards this complex interplay of a multitude of motives for perpetrator behavior and how film and photography circularly has affected in a more positive attitude towards violence against the targeted out-group. In this article I firstly want to reflect on a specific historical case to demonstrate the complexity of contextualizing, categorizing and analyzing perpetrator imagery. Subsequently I want to explore the diversity of motives for capturing atrocities and finally connect with some insights from social (neuro-) science how violent imagery affects a broader acceptance of violence as a legitimate means for a certain goal, like an exclusionary racial state. A clear example of such a complex visual perpetrator narrative is the massacre at the Lietūkis garage in Lithuania at the start of the Russian campaign in June 1941.

\section{The Report of a Photographer}

The imagery of the Holocaust consists of more than personal or official snapshots made in the camps. German soldiers, SS and local residents shot a vast amount of perpetrator photos and footage during the invasion of Poland and the Soviet Union. These photos portray not only the period of "Shoah by bullets" by German troops (Einsatzgruppen) but also the many atrocities committed by armed militia, auxiliaries and civilians. They were mostly brutal displays of collective violence targeting their Jewish residents and neighbors. ${ }^{23}$ One of these well-documented massacres occurred in the courtyard of the Lietūkis garage in Kovno, Lithuania on June 27, 1941. ${ }^{24}$ Wilhelm Gunsilius, a German Wehrmacht photographer from the Propaganda Kompanie (PK), reported and also took a series of photographs from this significant spectacle. ${ }^{25}$ As a PK photographer, he was a member of an advanced military unit and in search for quarters when he heard and saw a crowd of people in the forecourt of a garage in front of the cemetery in the center of Kovno. When he approached the courtyard, he saw a group of 40 to 50 Jewish residents, some very well dressed, that were being publicly humiliated, abused and one by one brutally killed by civilians with armbands and armed with rifles, shovels and iron crowbars. In his testimony, German colonel L.Von Bisschoffshausen stated that there "were women in the crowd and many of them clambered onto chairs and crates so that they and their children could get a better view of the 'spectacle' taking place in the yard below." ${ }^{26}$ As the site was probably also used as a horse stable, the courtyard was littered with animal droppings. The Jewish victims were herded and guarded by these Lithuanian auxiliaries and relentlessly battered. After they fell on their knees and were forced to gather the faeces, they were showered with a water hose and cleaned for a new round of abuse. ${ }^{27}$ Laimonas Noreika, a famous Lithuanian actor and poet, was at that time 15 years old and lived in Kovno. On that day, he witnessed together with his older brother the massacre at the Lietūkis garage. He testified that these events were deeply burned in is memory and that he would remember them until his death. He described how

in the middle of the yard, in broad daylight and in full view of the assembled crowd, a group of well dressed, spruce intelligent looking people held iron bars which they used to viciously beat another group of similarly well dressed, spruce, intelligent people. ... They kept hitting them until they lay inert. Then, using a hosepipe for washing cars, they doused them with

\footnotetext{
${ }^{23}$ The International School for Holocaust Studies, "The Eastern Front: Photographs as Propaganda," accessed May 1, 2017, http://www.yadvashem.org/yv/en/education/newsletter/29/photographs propaganda.asp; Judith Levin and Daniel Uziel, “Ordinary Men, Extraordinary Photos" Yad Vashem Studies no. 26 (1998), 276.

${ }^{24}$ The massacre is dated by some witnesses on $25^{\text {th }}$ and by others on the $27^{\text {th }}$ of June 1941.

${ }^{25}$ Klee, The good old days, 31-32.

${ }^{26}$ Holocaust Education \& Archive Research Team, "The Massacres in Kovno Reports and Eyewitness Accounts," accessed May 1, 2017, http://www.holocaustresearchproject.org/einsatz/kovnomassacres.html; "Augenzeugen der Pogrome auf dem Lietukis Garagenhof Kaunas 1941," History, Litauen (Fast) alles ueber Litauen!, accessed May 1, 2017, https:// www.alles-ueber-litauen.de/litauen-geschichte/lietukis-massaker-1941.html.

${ }^{27}$ Noreika Laimonas, "Oral history interview with Laimonas Noreika," United States Holocaust Memorial Museum, RG50.473*0096, accessed June 1, 2017, https://collections.ushmm.org/search/catalog/irn518271.
} 
water until they came round following which the abuse would start all over again. And so it went on and on until the hapless victims lay death. Bodies began to pile up everywhere. ${ }^{28}$

Laimonas watched the entire barbaric scene until his brother pulled him away. Among the assailants was a young Lithuanian blonde man, with rolled up sleeves and armed with a crowbar. He selected one man at the time from this group and would beat him with one or more blows to death. The German colonel Von Bisschoffshausen described the unknown perpetrator as follows:

However, when I asked what was happening I was told the 'death dealer of Kovno' is at work and he would make sure that all 'traitors and collaborators' received a fitting punishment for their 'treachery.' When I drew closer I witnessed a display of brutality that was unparalleled by anything I saw in combat during two world wars.... Standing on the tarmac in the yard was a fair haired young man of around 25. He leaned on a long iron bar as thick a human arm and around his feet lay between fifteen to twenty people who were either dying or already dead. A few feet away from him stood another group of individuals who were guarded by armed men. Every few minutes he signaled with his hand and another person quietly stepped forward and had his skull shattered with one blow from the huge iron bar the killer held in his hand. Each blow he struck drew another round of clapping and cheering from the enthralled crowd. ${ }^{29}$

Within the hour all these people were killed in this bestial manner. The many testimonies of this garage massacre confirm the reactions of the bystanders witnessing the events. They all specified that each murderous blow was accompanied by enthusiastic shouts from the audience. The German photographer Gunsilius reported that after the killings, the young man stood among the corpses and played with his accordion the Lithuanian national anthem. The large group of bystanders, including "women with small children on the first row," 30 clapped after each killing blow and sung or cheered during the final anthem. Upon asking, the photographer was informed that the parents of the perpetrator, "the death dealer of Kovno," were shot two days earlier because they were nationalists. It seems that the young man could have partly been driven by his urge to revenge the death of his parents and the manifold crimes by the Soviet NKVD (secret police) towards nationalistic Lithuanians. Of course, a complex interplay of (f)actors made this behavior possible, but that is not the scope of this article.

The remarkable aspect of this massacre is the openness in which this pogrom took place. A large group of Wehrmacht and SS soldiers, as the local population, not only witnessed the spectacle but also encouraged and energized the dynamics by cheering and clapping. In addition, the lack of any form of resistance, the non-intervention by the German soldiers and the abundant photographing and filming of this and similar events created an enabling space to commit these crimes that are described as Selbstreinigungsaktionen (self-cleaning actions) by Lithuanian partisan groups. ${ }^{31}$ Thousands of Jews perished over the next few days in related pogroms. In a similar manner, many German soldiers reported and photographed massacres, such as in Ponary (Panieriai), where a large number of Jews from Vilna were murdered in July 1941. ${ }^{32}$ Another example occurred in Zhitomir where a Wehrmacht vehicle with a megaphone informed the inhabitants and soldiers in German and Russian (Ukrainian) that Jews would be shot in the market place and that they should follow the lorry to the shooting. Soldiers were "sitting on rooftops and platforms watching the show." 33 Mass murder took the form of public entertainment and was generally photographed by those who were in the neighborhood.

\footnotetext{
${ }^{28}$ Holocaust Education \& Archive Research Team, The Massacres in Kovno Reports.

${ }^{29}$ Ibid.

${ }^{30}$ Klee, The good old days, 31-32.

${ }^{31}$ Elisabeth Boeckl-Klamper, "Pogrome in Kowno (Kaunas/Kauen), Juni 1941," Dokumentationsarchiv des österreichischen Widerstandes, accessed May 1, 2017, https://www.doew.at/erinnern/fotos-unddokumente/1938-1945/pogrome-in-kowno-kaunas-kauen-juni-1941.

${ }^{32}$ Klee, The good old days, 38-45.

${ }^{33}$ Ibid., 108-117.
} 
Despite it being illegal to photograph these atrocities, and sometimes there were attempts to prevent taking and sharing these photographs, that did not at all stop the universal tendency to watch and document the atrocities in the East. Gunsilius claimed that at the Lietūkis garage, an SS officer tried to confiscate his camera but was unsuccessful. As a frontline photographer from the PK, he had a special pass from the Sixteenth Army High Command stating that he could take photographs everywhere. He boldly informed the SS officer that he could take it up with Generalfeldmarschall Busch and was allowed to further capture the entire massacre. ${ }^{34}$ Another soldier and amateur photographer was less fortunate and had his camera confiscated but was able to save the film. ${ }^{35}$ Of all the massacres during that period, the incident at the garage was the most infamous one, probably due to the richness and large number of testimonies and photos. Elisabeth Boeckl-Klamper highlighted the fact that there are photos of the Lietūkis garage massacre in different European archives, which make us suspect that the photos were duplicated and shared among several soldiers. ${ }^{36}$ The nine massacre photos shown here were anonymously donated to the Documentation Centre of Austrian Resistance (DÖW) with the message that they were taken by a German soldier. They show the abuse, the humiliation and the killings but also the bystanders and the general openness of the events that occurred. Capturing the photos from such a close range and several perspectives leads us to wonder why and for what purpose the photographer made this series. It was, of course, his job to visually record the world he was in, but in relation to the testimonies, the many bystanders also expressed emotions of curiosity, arousal and bewilderment. This massacre occurred in the first days of the Russian campaign and (revenge) atrocities by local auxiliaries were probably a new phenomenon for the military troops. Being suddenly confronted with them questions how ordinary people ${ }^{37}$ would react in such an extraordinary situation. One might look away or speak out against it, be intrigued in the dynamics at play or just silently capture the situation out of curiosity and the urge to document the unbelievable. As Sontag said, "As photographs give people an imaginary possession of a past that is unreal, they also help people to take possession of space in which they are insecure." ${ }^{\prime 38}$ To understand these motives, we first need to contextualize, categorize and analyze the field of perpetrator photography.
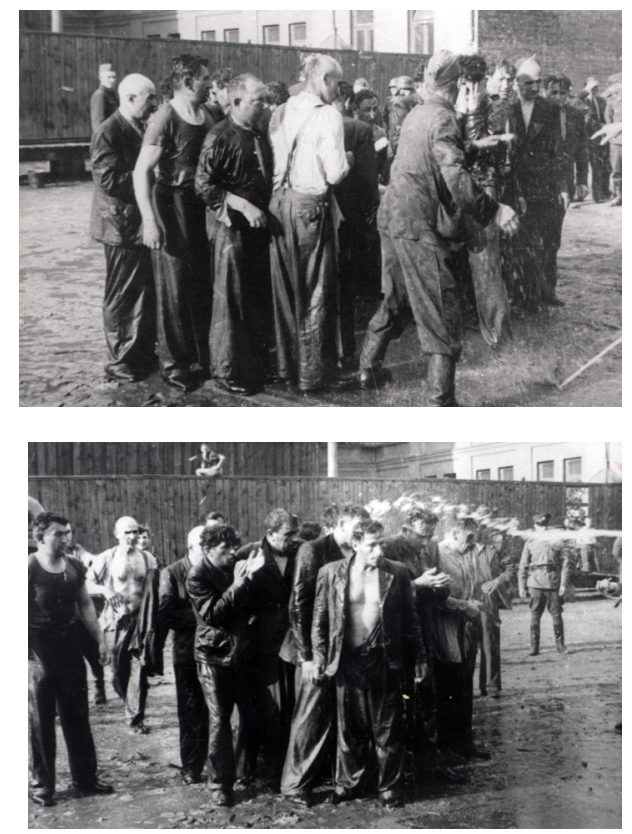
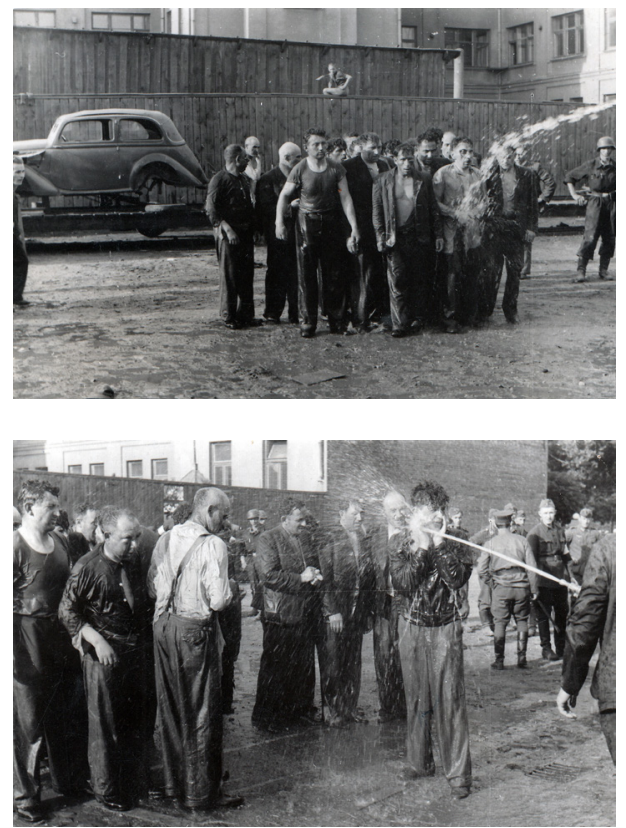

\footnotetext{
${ }^{34}$ Ibid., 32.

${ }^{35}$ Ibid., 33.

${ }^{36}$ Boeckl-Klamper, Pogrome in Kowno.

${ }^{37}$ Christopher R. Browning, Ordinary men: Reserve Police Battalion 101 and the Final Solution in Poland (New York: HarperCollins Publishers, 1993).

${ }^{38}$ Sontag, On photography, 9.
} 

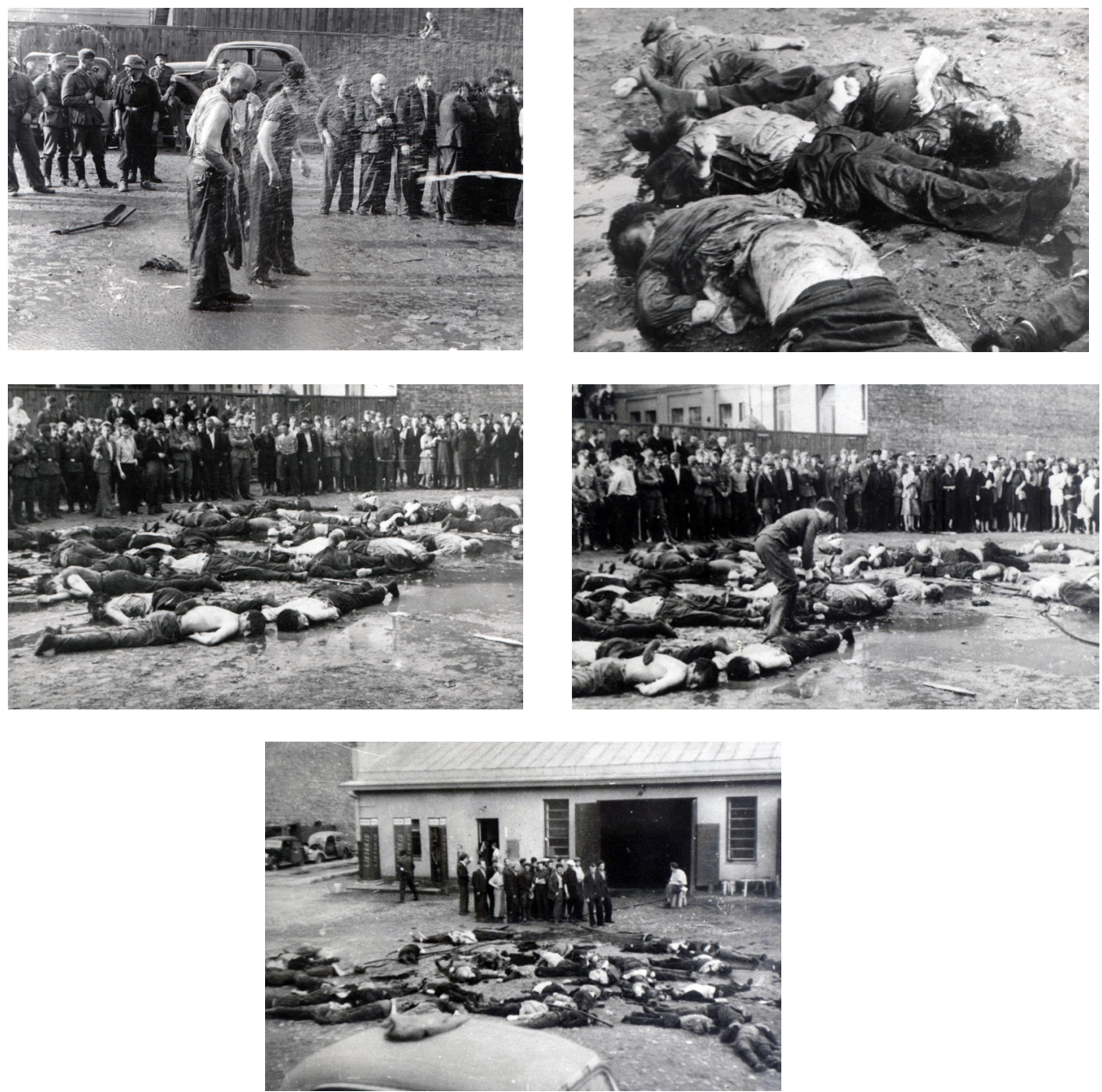

Nine photos that were anonymously donated to the Documentation Centre of Austrian Resistance (DÖW). The photos were taken by a German soldier at the Lietūkis garage massacre. They show the victims, perpetrators (Lithuanian auxiliaries) and several bystanders (locals and German soldiers) who witnessed the abuse, humiliation and brutal killings on June $27,1941 . .^{39}$

\section{Contextualizing Perpetrator Photography}

The imagery discussed here, atrocity and camp photography, cannot be explained without knowledge of the specific contexts in which they were made. The atrocities seen in the nine photos of the Lietūkis garage massacre would be difficult to deconstruct if we did not have so many witness testimonies available that dated and localized the events, clarified which actors were present and how we need to decipher this within the historical context of the Russian campaign during the summer of 1941 and the related crimes committed by local auxiliaries. Furthermore, we already mentioned the fact that the SS camp albums staged a framework of reference through an ideological lens in the final stage of a cumulative process of destruction. Perpetrator photography is difficult to analyze without additional information on who, what, when, where and why something was photographed. In contextualizing these visual documents, we need to reflect on the historiographical details of the captured situation as well as on the media channels and what new technological and societal advances have influenced these forms of communication. In this light, it is obvious that war photography is not a new phenomenon. Since the first use of cameras in the

${ }^{39}$ Archive DÖW collection, n.d., 2441/1-9. 
$19^{\text {th }}$ century, this technology has been also used on the battlefield for personal or propagandistic purposes. Together with its usage came the practice of censorship, because one soon realized that seeing was believing. Noel Whitty emphasized the strong relationship that always existed between governments, the military and media organizations in relation to the imagery of war. ${ }^{40}$ Governments, and also terrorist groups, are aware of the strong emotional and ideological potential that visual signs and narratives have. A clear example is the high level of attention the Nazis had for mass demonstrations and mass media. These highly visually orchestrated events created an intense sense of belonging. Hitler wrote in Mein Kampf that

mass demonstrations on the grand scale not only reinforce the will of the individual but they draw him still closer to the movement and help to create an esprit de corps.... [the individual] has need of that reinforcement which comes from the consciousness that he is a member of a great community. And only a mass demonstration can impress upon him the greatness of this community. ${ }^{41}$

Ross Corey demonstrated that the role of mass media entertainment functioned somewhere "between mobilization and distraction," ${ }^{42}$ and that this relation shifted throughout the course of the war: mobilizing first and distracting afterwards when the war opportunities turned against the Nazis. This dual approach resonated with new patterns of pleasure seeking, consumption and tourism on the one hand, and the need for "the cultivation of a wholesome and assimilationist national culture shared by all 'national comrades',"43 on the other hand. Vacation organizations such as Kraft durch Freude, the myriad of highly illustrated magazines like the Berliner Illustrierte Zeitung and Die Woche, anti-semitic films including Jud Süß, Der ewige Jude, Die Rothschilds, or highly successful movies such as Der Wunschkonzert or Die Große Liebe combined with the weekly news bulletins of the Wochenschau not only entertained but also intensively shaped a strong visual framework of reference based on past humiliations of a proud nation, the current patriotic and triumphant years and a permanent threat to the national community or Volksgemeinschaft. ${ }^{44}$ Furthermore, the radio was mass produced and widely distributed as an effective instrument with a blurry line between political and entertaining broadcasts. Publications such as Der Rundfunk als Führungsmittel (the radio as a guiding instrument) by Gerhard Eckert made it clear that the overall goal was binding the listeners with entertaining broadcasts to the radio and thereby make them more receptive for the political broadcasts that only took a small part of the broadcasting time. ${ }^{45}$

All available media channels and technological innovations were deployed in (group) identity politics. Habbo Knoch ${ }^{46}$ argued together with Paul Gerhard ${ }^{47}$ that mainly the imagery was the central component in creating the National Socialist Movement and the group's dominance. It was not the speeches and writing but the massive use of images and staged performances with Swastika flags and Hitler greeting people at mass meetings filmed by Leni Riefenstahl that created an affirmative space as breeding ground for the National Socialist community and their so-called superiority. The imagery created in this process can be seen as "collective reference points" and "visual anchors of the ruling policy." 48 It was evident, as Elisabeth Harvey described, that

\footnotetext{
${ }^{40}$ Noel Whitty, "Soldier Photography of Detainee Abuse in Iraq: Digital Technology, Human Rights and the Death of Baha Mousa," Human Rights Law Review 10, no. 4 (2010), 689.

${ }^{41}$ Adolf Hitler, Mein Kampf (English edition, 2015), 355.

${ }^{42}$ Corey Ross and Fabrice d'Almeida, "Radio, Film and Morale: Wartime Entertainment between Mobilization and Distraction," in Pleasure and Power in Nazi Germany, eds. Pamela E. Swett et al. (New York: Palgrave Macmillan, 2011$), 171$.

${ }^{43}$ Ibid., 155.

${ }^{44}$ Ibid., 160.

${ }^{45}$ Ibid., 163; Gerhard Eckert, Der Rundfunk als Führungsmittel, vol. 1, Studien zum Weltrundfunk und Fernsehrundfunk (Heidelberg: K. Vowinckel, 1941), 179.

${ }^{46}$ Habbo Knoch, "Die 'Volksgemeinschaft' der Bilder: Propaganda und Geselschaft im frühen Nationalsozialismus," in Attraktion der Nazibewegung, ed. Gudrun Brockhaus (Essen: Klartext, 2014), 133.

${ }^{47}$ Gerhard Paul, Aufstand der Bilder: die NS-Propaganda vor 1933 (Bonn: Dietz, 1992), 258.

${ }^{48}$ Knoch, Die 'Volksgemeinschaft' der Bilder, 134.
} 
"photography and photojournalism thus became forms of 'emotional management' that tried to tie the notion of spaces through pleasurable feelings associated with the Nazi New Order in Europe." 49 The camera became a key tool in building the national community and had already been widely available for the public since the Weimar period. Cheap and lightweight cameras, such as Leica, Ermanox, Kodak, Agfa and Voigtländer, were easily accessible in Germany, and their production rose during the Weimar years. ${ }^{50}$ In only two years since 1930, more than a million Agfa-boxes were sold, and by 1939 , more than $10 \%$ of the German population owned a camera. ${ }^{11}$ In summary, many German households were able to capture the world as an everyday practice. ${ }^{52}$

The emergence of the camera during these years created an "army of millions of amateur photographers" 53 and resulted in additional propaganda photos taken by a vast community of soldiers and community members who often used the many camera shops for development or reproduction and shared or traded their imagery as a social practice. The propagandistic imagery that was created and directed from the political center could now be amplified by the viewfinders of millions of amateur photographers. In an opening speech at the photo fair Die Kamera in Berlin in 1933, Joseph Goebbels addressed the topic of how "the experience of the individual has become a popular experience, and that only by the camera." ${ }^{54}$ In the article "Der neue Weg" (the new way) in the magazine Photofreund, the author defined how photography needed to become "a tool, a weapon" to portray and shape the "German spirit and sentiment."

We ought and want to create a German photography ... The heart must speak in it, the German heart; the spirit must form it, the German spirit; sentiment must be tangible in it, German sentiment; and from this the new German photo will be born ... The German people have been rapidly united in the spirit of National Socialism ... All that seems in some way appropriate and good should and must be placed at the service of this tremendous idea, and thus photography too is called upon to help and contribute ... Photography should no longer distract from the struggle; no, it should lead into the midst of the tray and become a tool, a weapon in this struggle. The fact that it can be an explosive and powerful weapon is something the men of the new Germany have recognized clearly. Let the Führer determine the direction in which photography should develop..$^{55}$

Photography was not to be used solely as an individual experience but mainly as a tool to rise in the masses or the new national community. Alien elements (Fremdkörper) had no place in this new Germany. Janina Struk explained how all opponents of the state were seen as undesirable, with the Jew as the primary target. ${ }^{56}$ This mythical Jew had many disguises and was portrayed in anti-Semitic publications, such as the newspaper Der Stürmer with its slogan 'the Jews are our misfortune' or their book Der Giftpilz (poisonous mushroom) intended to indoctrinate youngsters, as so-called carriers of disease, lacking in morality, parasitize on the society and infecting all that was pure and good. Goebbels clarified in the chapter titled Die Juden sind Schuld (The Jews are to blame) that the nation was in a war with these unwanted alien elements:

\footnotetext{
${ }^{49}$ Elizabeth Harvey, "Seeing the World: Photography, Photojournalism and Visual Pleasure in the Third Reich," in Pleasure and Power in Nazi Germany, eds. Pamela E. Swett et al. (New York: Palgrave Macmillan, 2011), 178.

${ }^{50}$ Susie Linfield, The Cruel Radiance: Photography and Political Violence (Chicago: University of Chicago, 2012$), 67$.

${ }^{51}$ Michael Wildt, "Picturing Exclusion: Race, Honor, and Anti-Semitic Violence in Nazi Germany before the Second World War," in Violence and visibility in modern history, eds. Jürgen Martschukat and Silvan Niedermeier (New York: Palgrave Macmillan, 2015), 140.

${ }^{52}$ Linfield, The Cruel Radiance, 67.

${ }^{53}$ Petra Bopp, "Images of Violence in Wehrmacht Soldiers' Private Photo Albums," in Violence and visibility in modern history, eds. Jürgen Matschukat and Silvan Niedermeier (New York: Palgrave Macmillan, 2015), 2.

${ }^{54}$ Rolf Sachsse, "“Es wird nochmals ausdrücklichst darauf hingewiesen...' Aspekte der Bildzensur im NS-Staat und im Zweiten Weltkrieg," in Fotografieren verboten! Heimliche Aufnahmen von der Zerstörung Kölns, eds. Thomas Deres and Martin Rüther (Köln: Emons, 1995), 12.

${ }^{55}$ C.A. Kanitzberg, “Der neue Weg." Photofreund 1933, no. 13 (July 29, 1933), 259-260; Struk, Photographing the Holocaust, 23.

${ }^{56}$ Struk, Photographing the Holocaust, 20.
} 
For their sake alone we must win the war. If we lose it, these harmless-looking Jewish chaps would suddenly become raging wolves. They would attack our women and children to carry out revenge. There are enough examples in history. That is what they did in Bessarabia and the Baltic states when Bolshevism marched in, even though neither the people nor their governments had done anything to them. There is no turning back in our battle against the Jews - even if we wanted to, which we do not. The Jews must be removed from the German community, for they endanger our national unity. ${ }^{57}$

The Nazi visual representation of this mythical Jew fit this centrifugal framework of reference. Stereotypical images portrayed the Jew as a threat to society. This visual framework was gradually created through articles focusing on the alien types present in society and that the community needed to be protected against them. As a striking example, the magazine Illustrierter Beobachter published a special article on the Dachau concentration camp on 3 December $1936 .{ }^{58}$ In a fourpage photo essay by Friedrich Franz Bauer, "three typical subhuman specimens in the Dachau concentration camp" were shown: "the communist, the work shy professional criminal and the Jewish national (Volks)criminal." Lombrosian typologies and characteristics were used to visually categorize the threat. On June 28, 1933, the Coburger Zeitung described the Dachau camp as a program that needed to traceless eradicate the "sick and alien part of the German Blood". More than $80 \%$ of the prisoners at Dachau were "bastards of mixed race with Jewish, Negroid, Mongolian or - the devil may know - any other types of blood attack." ${ }^{59}$ Nazi propaganda was stuffed with this kind of speech and imagery showing facial and physical features and the accompanying mug shots of the criminal type..$^{60}$ The most shocking representation that divided Us from Them was the SS publication Der Untermensch that was translated in many European languages for maximal dissemination. ${ }^{61}$ The publication was similar to the newspaper Der Stürmer in that it was freely available in the many newspaper boards erected in the public space and used the tactics of naming and shaming to maximize the separating forces. In local editions, Germans who bought from Jewish shops were named in the magazine and considered to be traitors to the community. ${ }^{62}$ In a similar manner, the German population was warned during the national boycott on April 1, 1933 with posters and slogans that stated, "Jewish Business! Whoever buys here will be photographed!"63 Footage of these boycotts was widely shown in several screenings of the Wochenschau newsreels in April 1933. ${ }^{64}$ These specific and recurring events created a Manichaean view and representation of German society.

\footnotetext{
${ }^{57}$ Joseph Goebbels, Das eherne Herz. Reden und Aufsätze (München: Zentralverlag der NSDAP, 1942), 85.

${ }^{58}$ Struk, Photographing the Holocaust, 20.

${ }^{59}$ Hans Dietrich, "Bericht des NSDAP-Reichstagsabgeordneten," Coburger Zeitung, June 28, 1933.

${ }^{60}$ Struk, Photographing the Holocaust, 17.

${ }^{61}$ Der Reichsführer SS. Der Untermensch (Berlin: Nordland-Verlag GMBH, 1942).

${ }^{62}$ Wildt, Picturing Exclusion, 142.

${ }^{63}$ Sybil Milton, "The Camera as Weapon: Documentary Photography and the Holocaust," Simon Wiesenthal Center Annual no. 1 (1984), 45-68, accessed May 1, 2017, http://motlc.wiesenthal.com/site/pp.asp?b=394975\&c=gvKVLcMVIuG.

${ }^{64}$ More specific: “Boykottaktion gegen jüdische Geschäfte in Berlin,” Deulig Tonwoche, nr. 66, 1933 (DTW 66/1933) and Fox Tönende Wochenschau 1933 (2600/1933). See: Peter Bucher, Wochenschauen und Dokumentarfilme 1895-1950 im Bundesarchiv-Filmarchiv (Koblenz: Bundesarchiv, 2000), 29.
} 


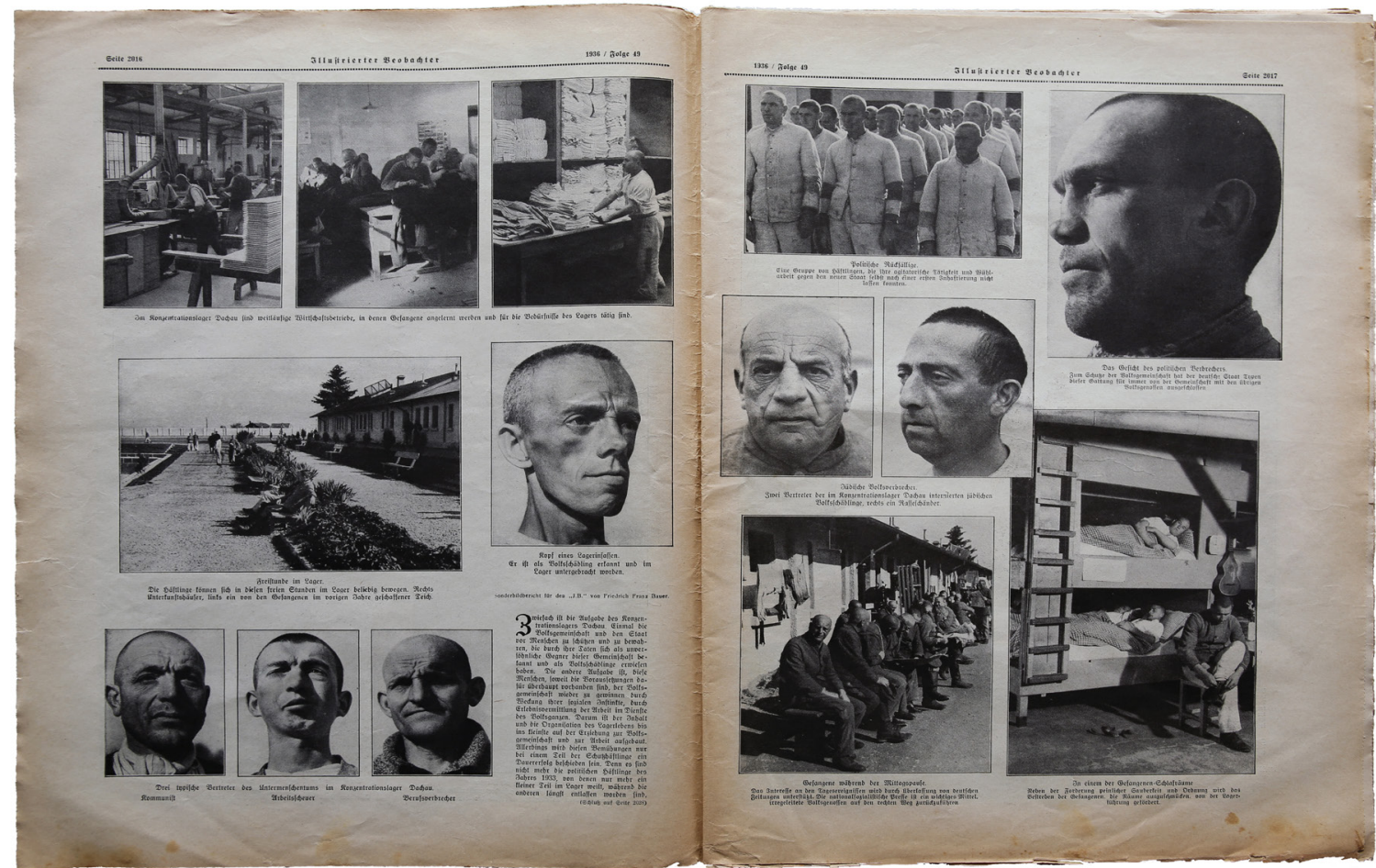

Photo report on the concentration camp Dachau in the Illustrierter Beobachter, December 3, 1936. Photos taken by Friedrich Franz Bauer. One of the photo captions reads: "The face of the political criminal. To protect the national community, the German state has excluded forever these types of this category from the fellowship with the rest of the people." ${ }^{65}$
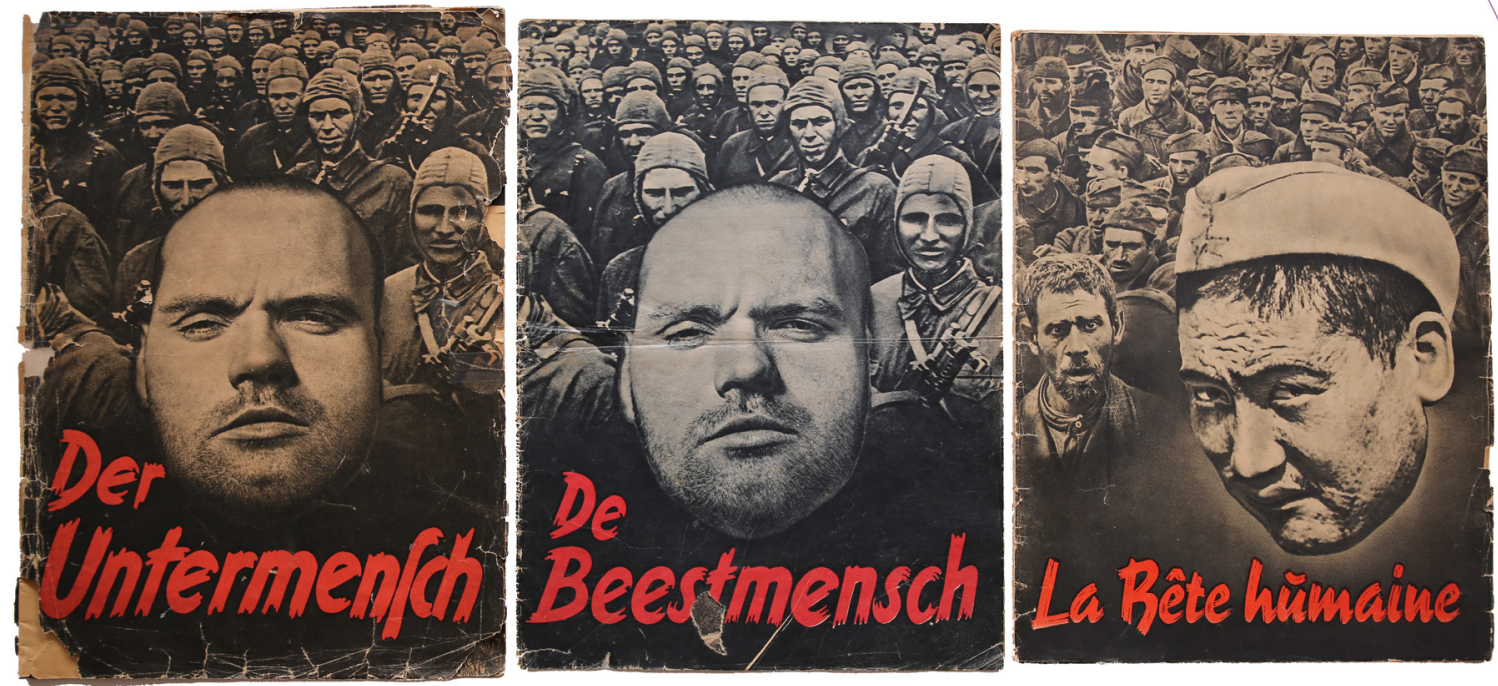

Three-language versions of the SS magazine Der Untermensch, published by the Reichsführer-SS in 1942. The publication extremely positioned the Untermensch (Jews/Soviets) against the Übermensch (Aryans) and was widely distributed in Nazi Germany and occupied countries. ${ }^{66}$

\footnotetext{
${ }^{65}$ Author's personal collection.

${ }^{66}$ Author's personal collection.
} 
The mythical Jew was created not only through such propaganda efforts but also with the active participation of the public. ${ }^{67}$ Thousands of visitors went to the Der ewige Jude exhibition that opened in Munich, Vienna and later toured to other major cities in the occupied territories. ${ }^{68}$ Many visitors bought the exhibition booklet or the postcard with the eternal Jew on it to keep as a souvenir or to mail to their acquaintances just as the wider public participated in the humiliation of Jews and Germans who committed the crime of Rassenschande (racial dishonour) through their relationships. During the run of the Neurenberg race laws, the number of cases of public humiliation rose to a maximum, as illustrated extensively in special editions of der Stürmer. Picturing the Jews' exclusion from the national community ("aus der Volksgemeinschaft gestoßen") was widespread. Michael Wildt mentions the story of a couple that was publicly humiliated for racial dishonor in Norden (northern Germany) on July 22, 1935. ${ }^{69}$ They were publicly exposed and photographed with placards around their neck stating, "I'm a race defiler" and "I am a German girl and let myself be defiled by a Jew." A German pharmacist who witnessed and photographed the events decided later to put a print of this photo in his shop window. Photography was no longer a means of creative expression but a political tool to create a superior national community. Michael Wildt referred to this calibrated practice when he analyzed the numerous photos taken by German Wehrmacht soldiers during their military campaigns. ${ }^{70}$ Apart from the everyday scenes, they photographed the gruesome executions as just a reality that was present. "At the same time, the photos position the photographing actors in the process, give self-descriptions and self-understanding of the soldiers and lead to questions about their perceptions and presentations of themselves and their actions, after consent, participation or distance." ${ }^{71}$ Thousands of community members and soldiers were "keen photographers" ${ }^{72}$ of the new societal order to which they contributed and were incrementally exposed.

\section{Categorizing and Analyzing Perpetrator Photography}

The diverse assemblage of perpetrator photography complicates an easy classification and analysis. The imagery can be sorted on the basis of the photographer's identity, the perspective and intention, the context of origin or the wider socio-political context, elements of composition (framing, exposure, distance and sharpness), the aesthetics and attractiveness, the impact and (mis)uses that the imagery has, the people or things that are presented, who took or shared the image, if it was an official or unofficial/amateur recording and finally, how the relation between the photographer and the subject could be defined. ${ }^{73}$ The one thing that is clear is that the photographs all were taken for a variety of official and/or personal reasons. Due to my later focus on the motives and effects of perpetrator photography, I have chosen to categorize the imagery here in those pictures that were produced, and sometimes censored, for official purposes and those that were produced for personal reasons, with particular reflection on some of the aspects of atrocity photography.

The official imagery of the Third Reich was one that was controlled through instructions and censorship. ${ }^{74}$ After the Nazi power takeover in 1933, the official image in politics was swiftly incorporated by the new regime. Photos of armed SA members who patrolled the streets together with regular police officers or the well-documented arrests of political opponents and their supposedly re-education in camps like Oranienburg, showed the public who was in power. The

\footnotetext{
${ }^{67}$ Struk, Photographing the Holocaust, 64.

${ }^{68}$ Ibid., 20.

${ }^{69}$ Wildt, Picturing Exclusion, 137-140.

${ }^{70}$ Ibid., 140.

${ }^{71}$ Wildt, Die Epochenzäsur, 369-340.

${ }^{72}$ Photoblätter, vol. 18 (1941), 29. As quoted in: Bopp, Images of Violence, 181.

${ }^{73}$ Milton, The Camera as Weapon, 45-68; Thomas White, et al., "Dehumanization and Incitement: The Use and Abuse of Holocaust Photographs and Images," Cohen Center for Holocaust and Genocide Studies, handout, accessed May 1 , 2017, http://www.keene.edu/academics/ah/cchgs/resources/educational-handouts/decoding-images/download/.

${ }^{74}$ Sachsse, Aspekte der Bildzensur, 14.
} 
overall purpose was to disturb the former structures of media organisations and to transform and secure the new media architecture based on clear ideological objectives and totalitarian methods. ${ }^{75}$ A prominent example was the illustrated article in the Völkischen Beobachter on August 8, 1933 regarding the intake of six new prisoners in KZ Oranienburg near Berlin. During the evening, social democrats Friedrich Ebert Jr and Ernst Heilmann were locked up together with four leading officials of the German radio. Among them were directors Dr Kurt Magnus and Heinrich Giesecke, the radio presenter Alfred Braun and the intendant of the Berlin radio hour, Hans Flesh. ${ }^{76}$ The former prisoner Gerhart Seger, who wrote the book Oranienburg, First authentic report of a fugitive escaped from the concentration camp in 1934, described in detail how these six leading civil servants were humiliated in public. ${ }^{77}$ Their imprisonment was shown widely in the German media and can be seen as a reckoning with the radio system of the Weimar republic and the Nazification of the media (Gleichschaltung). Furthermore, all photojournalists were obliged to join the new organization for photojournalists (Bildberichtstatter) within the Reich Association of the German Press (Reichsverband der Deutschen Presse). ${ }^{78}$

This system of total control and coordination was also the case in the several propaganda units that were installed in the army, the navy and air force. These PK photographers and camera operators received basic military training and served alongside the frontline units, suffering the same casualty numbers. ${ }^{79}$ What they captured was hard to control in these chaotic spaces, but of course afterwards, a deliberate selection was made for propaganda uses. Similar to how Gunsilius had and utilized the freedom to photograph the garage massacre in Kovno, PK Sonderführer Albert Cusian captured the creation of the Warsaw ghetto during 1939 and 1940. With his Leica camera and a 3.5 Elmar lens, he meticulously documented the life and suffering of the Jewish inhabitants: "I photographed everything in sight. The subject matter was so interesting. I took pictures in the morgue and at the Jewish cemetery. Bodies of Jews who had died during the night were laid out on the pavements for collection in the morning. I'd wait until the collectors came and then take pictures of them." ${ }^{80}$ The war effort had its official lens and censorship, so the imagery was deployed carefully to win the hearts and minds of the national community. Millions of photos found their way to selected target groups in a variety of magazines from illustrated newspapers, to tourist magazines such as Kraft und Freude, to special magazines for the Hitlerjugend or Bund Deutcher Maedel and the anti-Semitic publications by Der Stürmer. The imagery was selected, edited, cropped and printed to maximize its propagandistic effects. A solid example of this is the photo that was made in the fall of 1939 in occupied Poland. In this photo, we see a German soldier harassing a Jew during forced labor. Two other soldiers are watching this together with two small children who observed the situation at the edge of the pit. ${ }^{81}$ The photo was released in a series of articles in Der Stürmer focusing on the forced deployment of Jews in the East. But the final image that was used for publication was cropped so that the two children who stand on the edge were no longer visible in the picture. ${ }^{82}$ Around the same period, the German newsreels (Wochenschau) showed similar footage of forced Jewish labor that was filmed during the occupation of Poland and

\footnotetext{
${ }^{75}$ Ibid.

${ }^{76}$ Stiftung Brandenburgische Gedenkstätten, “VI. Wie Ebert, Heilmann und die Leiter des Rundfunks eingeliefert wurden," Die politischen Häftlingen des Konzentrationslager Oranienburg, accessed May 1, 2017, http://www.stiftung-bg. de/kz-oranienburg/index.php?id=37.

${ }^{77}$ Gerhart Seger, Oranienburg: erster authentischer Bericht eines aus dem Konzentrationslager Geflüchteten (Karlsbad: Verlagsanstalt Graphia, 1934), 41-42.

${ }^{78}$ Harvey, Seeing the World, 180.

${ }^{79}$ Phillip Knightley, The First Casualty: The War Correspondent as Hero and Myth-Maker from the Crimea to Iraq (Baltimore: Johns Hopkins University Press, 2004), 241.

${ }^{80}$ Ibid., 241.

${ }^{81}$ Volkhard Knigge, et al., Forced labor: the Germans, the forced laborers, and the war: companion volume to the exhibition (Weimar: Buchenwald and Mittelbau-Dora Memorials Foundation), 2010.

${ }^{82}$ Stiftung Gedenkstätten Buchenwald und Mittelbau-Dora, “Fotos: Radikalisierung. Zwangsarbeit im besetzten Europa," Ausstellung Zwangsarbeit - Presseinformation, accessed May 1, 2017, http://www.ausstellung-zwangsarbeit. org/aktuelles/presseinformation/?L=0.
} 
later the Soviet Union in $1941 .{ }^{83}$ The central topic in these bulletins was that the 'work-shy' Jews were now dominated by Germany and forced to work.

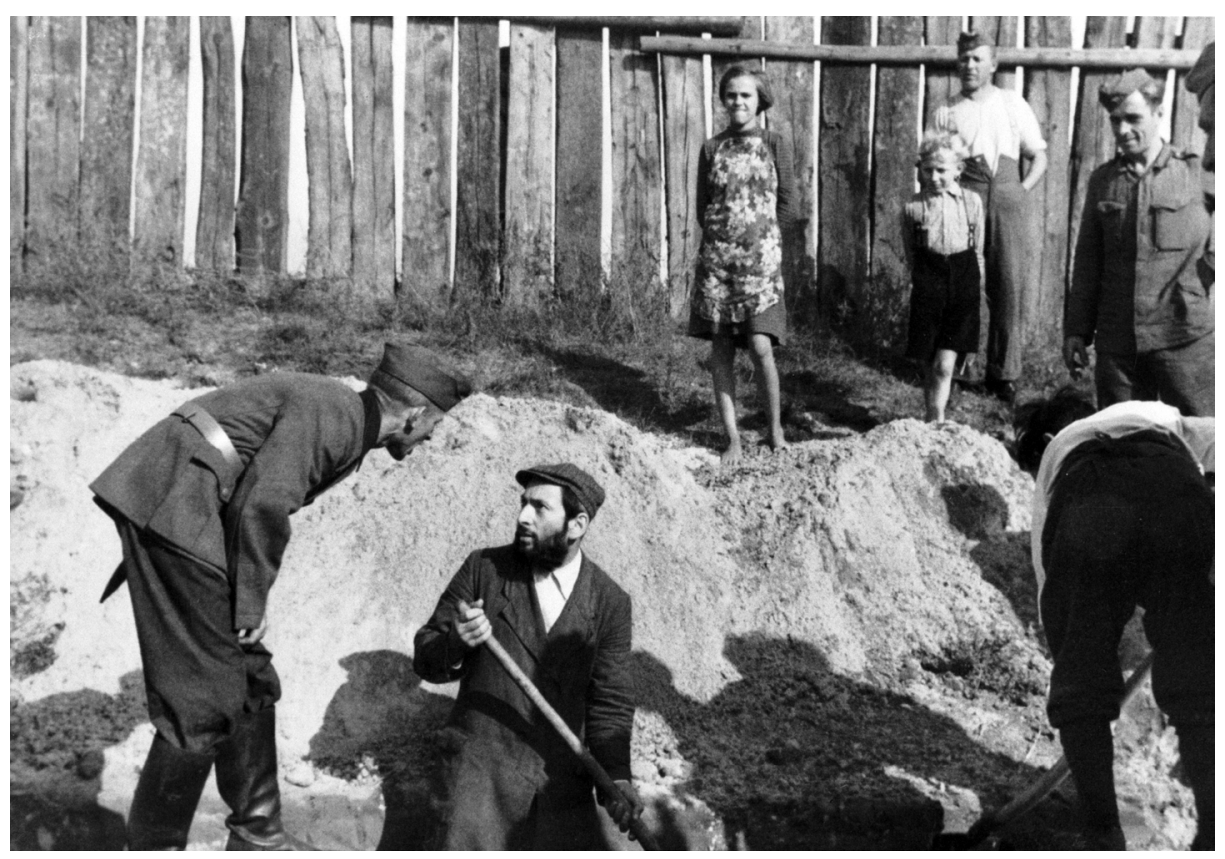

A German soldier harasses a Jew during forced labor in occupied Poland in the fall of 1939. A part of the photo was used by the anti-Semitic newspaper Der Stürmer without the two children observing the humiliation. ${ }^{84}$

Next to war photography for propagandistic uses, official photography was also set up within the camp administrations. Since 1933, documentary photos and albums had been made in the operation of camps such as Oranienburg and Dachau. This imagery was widely published in popular news media or books like the anti-Brown Book on the first concentration camp Oranienburg by SA camp commander Werner Schäfer. ${ }^{85}$ Such publications and photo albums were made for the Nazi hierarchy and broader public to present the camp as an effective instrument of re-education. Later, the larger camps had their own photographic service (Erkennungsdienst) under the administration department, which produced and developed the imagery in and round the camp system. They took mug shots of prisoners for the administrative records, photos of the architecture and erection of the camp's infrastructure, photos of suicides or medical experiments, the SS households, social activities, SS military parades, official portraits and, of course, the official visits by high-ranking officers. ${ }^{86}$ This capturing of everyday life contributed to the normality of the entire operation. ${ }^{87}$ Photos of high-ranking visits, camaraderie, social activities at the SS Küche (kitchen barracks) and

\footnotetext{
${ }^{83}$ More specific: "Polnische Juden bei Aufräumungsarbeiten," Ufa Tonwoche, nr. 475, 42, 1939 (UTW 475/1939); "Aufräumungsarbeiten durch jüdische Bevölkerung," Deutsche Wochenschau, nr. 567, 30, 1941 (DW567/1941) and "Arbeitseinsatz von Juden," Deutsche Wochenschau, nr. 570, 33, 1941 (DW 570/1941). Also see, Bucher, Wochenschauen, 88 and 110.

${ }^{84}$ Stadtarchiv Nürnberg collection, n.d., E39 nr. 1703/21.

${ }^{85}$ Werner Schäfer, Konzentrationslager Oranienburg. Das Anti-Braunbuch über das erste deutsche Konzentrationslager (Berlin: Buch u. Tiefdruckgeselschaft m.b.h., Abt. Buchverlag), 1934.

${ }^{86}$ Brasse, Wilhelm Brasse, Fotograf, 11-17; Struk, Photographing the Holocaust, 102-116.

${ }^{87}$ Pflug, Gabriele, ed., Das sichtbare Unfassbare: Fotografien vom Konzentrationslager Mauthausen: Katalog zur gleichnamigen Ausstellung = The visible part: photographs of Mauthausen Concentration Camp (Wien: Mandelbaum Verlag, 2005), 122.
} 
the Führerheim for officers, the camp zoos and the simple and tidy quarters gave confirmation to the lower ranks that everything was legitimate and also created a space of connectedness, a unique bond with a higher purpose. It projected hierarchy, structure, order, elite awareness and above all, comradeship. ${ }^{88}$
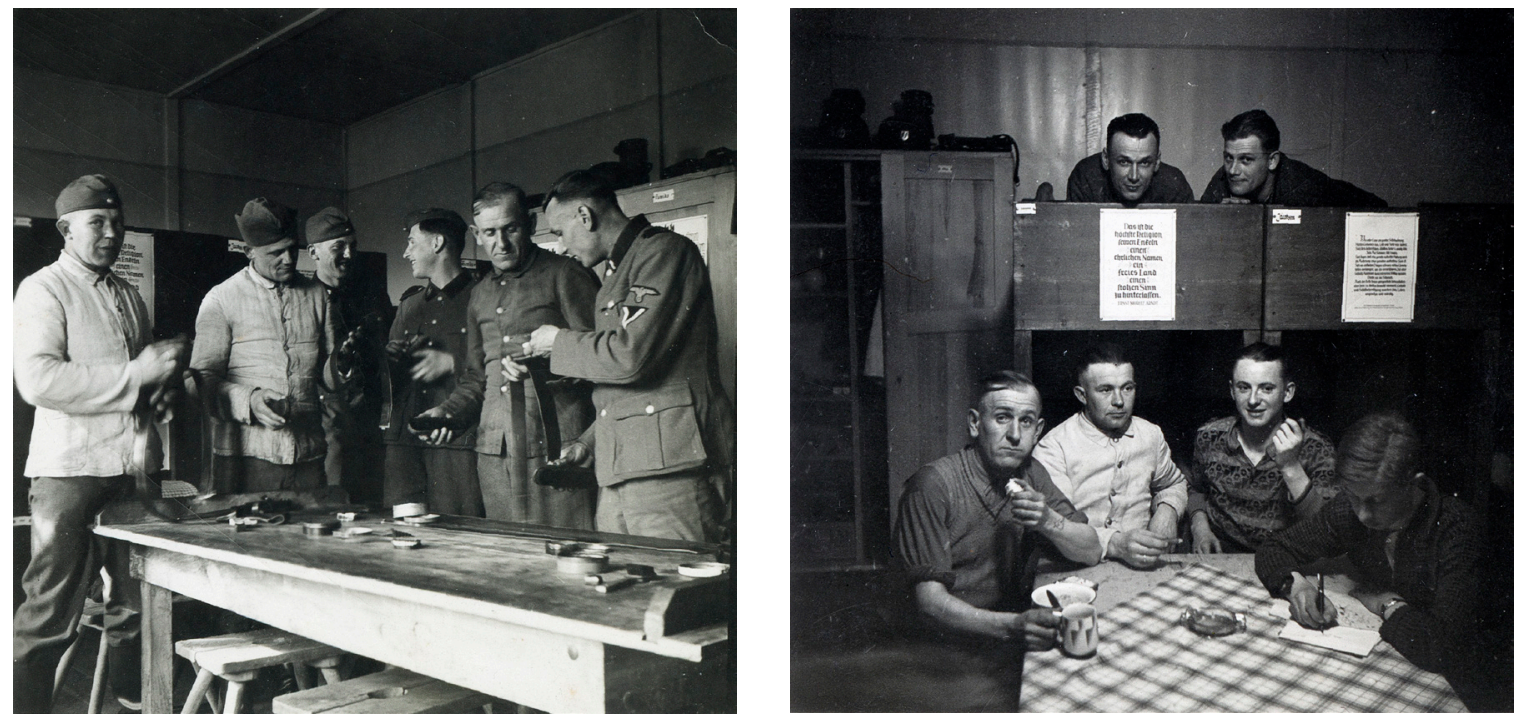

Two photos from a personal album showing the simple and tidy quarters of the guards at the Neuengamme concentration camp, $1941 .{ }^{89}$

The pictures were often reproduced, made into postcards and sold to the camp guards "as souvenirs to be hung on the wall and looked at later," ${ }^{\prime 90}$ similar to what Franz and Höcker had done when creating their visual memory albums. SS guards posted a postcard made by the Erkennungsdienst of Auschwitz of the Solahütte in 1941 to the home front showing the idyllic space of the Beskiden, which was 30 kilometers from the camp complex. It was a place where the SS guards could relax when they were off duty or during team building. ${ }^{91}$ The postcard was made by the photo department in Auschwitz I, in the same way the team-building photos from the Höcker album had been created at the Solahütte. This unique collection has demonstrated SS comradeship and SS service after the killing of more than 320,000 Hungarian Jews during Aktion Höss. These binding images showed not only the elite family or SS community and their absolute dominance but also the need for a normal social life and leisure time. ${ }^{92}$ It confronts us not with the demonic characteristics of the perpetrators but rather with the "banality of evil" and the total exclusion of their murderous actions to others from their own moral world. The victims were no longer human beings but a job to be done, and after that job, these SS men and women brought their kids to the SS kindergarten, went to the opera at the SS Küche and participated in a normal social life in and around the camp complex. The many official and personal photos of atrocities and normal social life display the parallel worlds and separately bind both the victim and perpetrator group to their own reality.

\footnotetext{
${ }^{88}$ Ibid., 114.

${ }^{89}$ Author's personal collection.

${ }^{90}$ Ibid., 108.

${ }^{91}$ Piotr Setkiewicz, "Außenkommando SS-Hütte Solatal," in Das Höcker-Album Auschwitz durch die Linse der SS, eds. Christophe Busch, et al. (Darmstadt: Von Zabern, 2016), 168.

${ }_{92}$ Christophe Busch, "Karl-Friedrich Gottlieb Höcker, der Adjutant von Lublin und Auschwitz," in Das Höcker-Album Auschwitz durch die Linse der SS, eds. Christophe Busch, et al. (Darmstadt: Von Zabern, 2016), 60-62.
} 


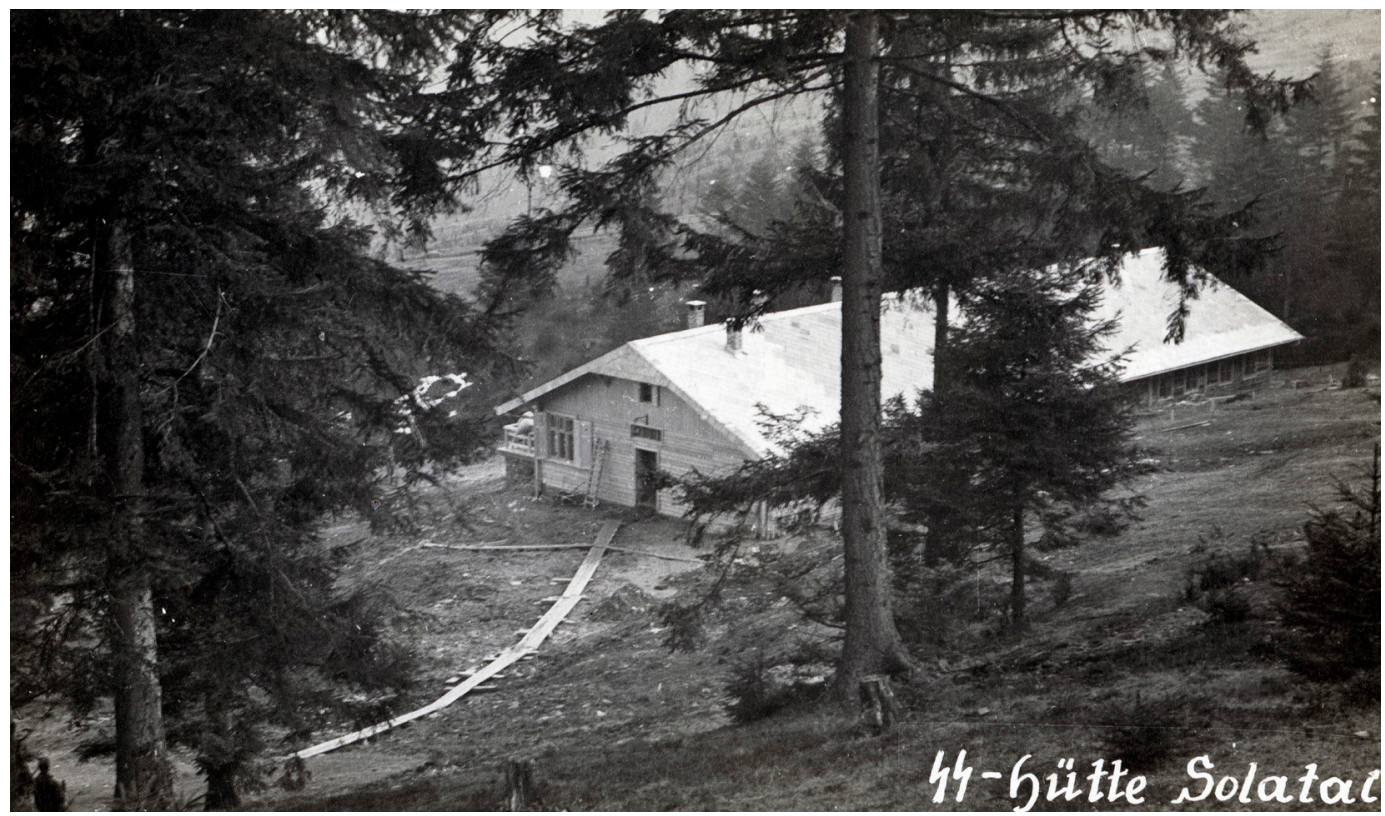

A postcard of the SS-Hütte Solatal, still in construction, near the Auschwitz camp complex, 1941. The postcard was sent by a SS-Mann from the second company of the SS-Totenkopf battalion. These postcards were made by the Erkennungsdienst in Auschwitz 1 and sold to the soldiers. ${ }^{93}$

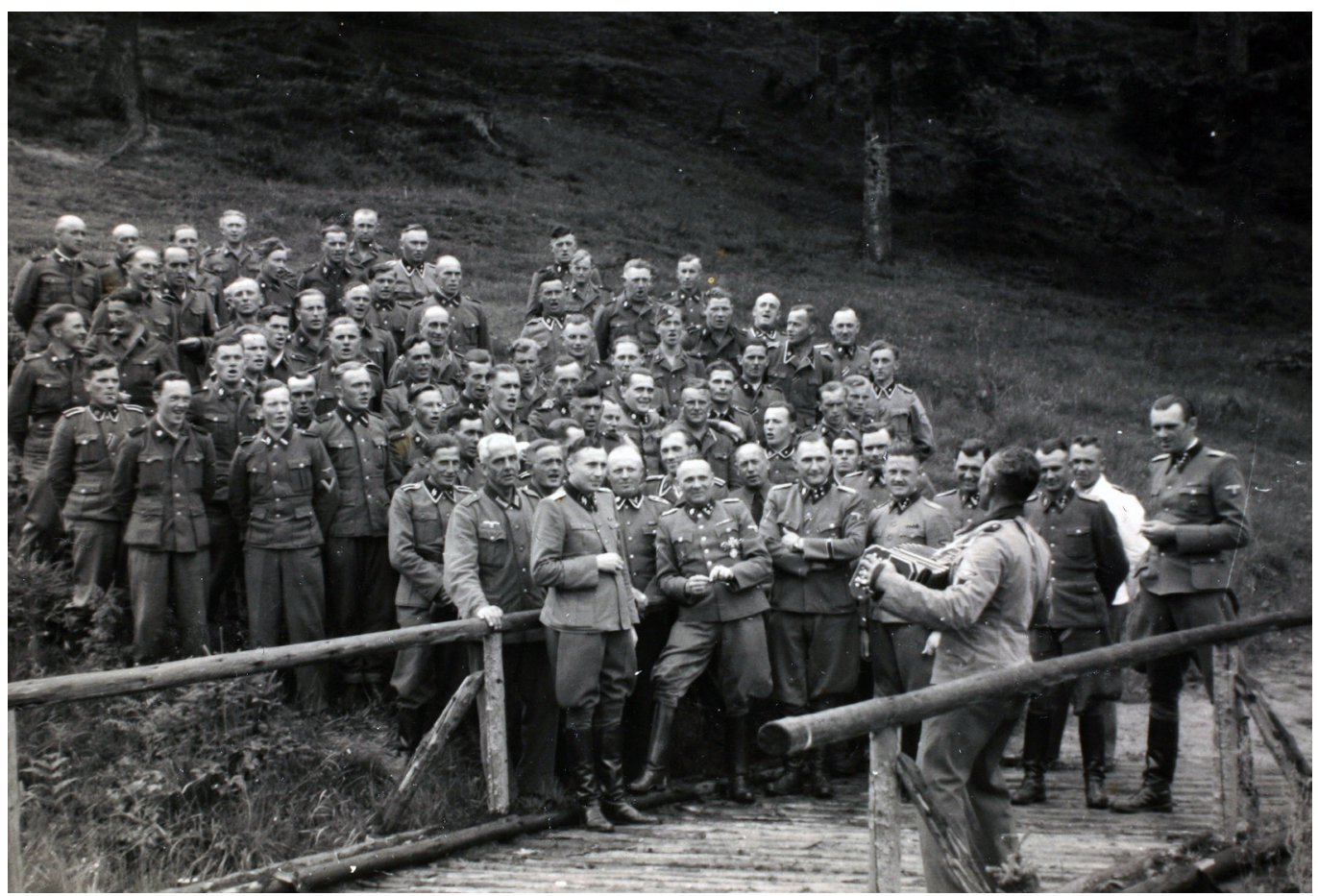

The staff of the Auschwitz complex posing on the bridge in front of the Solahütte, 15 July 1944. The photo shows a team-building day just after the murder of 320,000 Hungarian Jews, called Aktion Höss. ${ }^{94}$

\footnotetext{
${ }^{93}$ Author's personal collection.

${ }^{94}$ United States Holocaust Memorial Museum collection, n.d., photo-nr. 34739.
} 
The official Nazi photography was coordinated and controlled, but intertwined with personal amateur photography. Several guards in the camps, as well as soldiers on the battlefield, owned a camera. SS-Obersturmführer Walter Schmidetzki, head of the Kanada II barracks for stolen goods in Birkenau, can be seen holding a camera in a picture of the Solahütte photo series. ${ }^{95}$ In spite of the restrictions with photographing in the camps, as frequently stated in the Kommandanturbefehle (commandant orders) by camp commander Höss, ${ }^{96}$ the Erkennungsdienst and the photo shops in the city of Oświęcim had their work to develop all the personal pictures that were made by the SS or their family members living there. Sandra Stark states in her article Papa macht Witzen, SS Soldaten als Knipser that a lot of photographs were made on the weekend. ${ }^{97}$ Making family albums seemed to be a favorite pastime when the guards were off duty. In addition, the family members that lived near the camp, mostly family of officers, were capturing their lives and providing us insight into their supporting social activities and sometimes also their ideological framework of reference. The images of the private lives of the SS officers showed a comfortable degree of luxury, far away from the war reality in which Germany was involved. Photos of the children, an often photographed subject, occasionally showed a young Polish house maid who took care of the children and the household. ${ }^{8}$ Some of these Polish girls testified of the horror they witnessed, but others had fine memories of the family and even possessed some photos together with them or kept in touch after the family moved. ${ }^{99}$

The collections and albums of personal and official imagery regularly included some atrocity photos. This imagery spans a continuum that starts with documenting bodies of past atrocities to taking pictures during the process of humiliation, abuse and even killing. The spectrum shifts from a more passive documenting approach ${ }^{100}$, as a souvenir or talisman ${ }^{101}$, to the direction of a more active dominating approach, as visual trophies ${ }^{102}$ or rituals of dominance ${ }^{103}$. Both ends of this spectrum of atrocity photography can be seen as acts of perpetration. I fully agree with Sontag who stated that "there is something predatory in the act of taking a picture. To photograph people is to violate them, by seeing them as they never see themselves, by having knowledge of them they can never have; it turns people into objects that can be symbolically possessed. Just as the camera is a sublimation of the gun, to photograph someone is a sublimated murder - a soft murder, appropriate to a sad, frightened time." 104 The difference between this passive documenting approach and the active dominating approach is that the first one works mainly indirectly. By capturing, presenting and sharing the imagery of atrocities (ex post facto), they are influencing the general framework of reference, "de-subjectifying" the victims and neutralizing normal inhibitions we have towards the perpetration of such atrocities. ${ }^{105}$ The imagery creates an enabling space or sets a stage where the other is outlawed, even if this passive form of perpetration is motivated by "a mixture of disbelief, repulsion and feelings of discomfort, combined with curiosity." 106 The second approach is much

${ }^{95}$ Christophe Busch, et al., eds. Das Höcker-Album: Auschwitz durch die Linse der SS (Darmstadt: Von Zabern, 2016$), 198$.

${ }^{96}$ Norbert Frei, et al. Standort- und Kommandanturbefehle des Konzentrationslagers Auschwitz 1940-1945 (München: K. G. Saur, 2000), 8, 214, 422

${ }^{97}$ Sandra Starke, “'Papi macht Witzchen' SS-Soldaten als Knipser," (lecture, June 6, 2008), Medienamateure: Wie verändern Laien unsere visuelle Kultur, 3.

${ }^{98}$ Piotr Setkiewicz, The Private lives of the Auschwitz SS (Oświęcim: Auschwitz-Birkenau State Museum, 2014), 22.

${ }^{99}$ Ibid., 9

${ }^{100}$ Bernd Hüppauf, “Emptying the Gaze: Framing Violence through the Viewfinder," New German Critique, no. 72 (1997), 36.

${ }^{101}$ Kathrin Hoffmann-Curtius, “Trophäen in Brief-Taschen - Fotos von Wehrmachts-, SS- und PolizeiVerbrechen," Kunsttexte.de, no. 3 (2002), 8.

102 Jürgen Martschukat and Silvan Niedermeier, "Violence and Visibility: Historical and Theoretical Perspectives," in Violence and visibility in modern history, eds. Jürgen Martschukat and Silvan Niedermeier (New York: Palgrave Macmillan, 2015), 1.

${ }^{103}$ Alexander B. Rossino, “Eastern Europe through German eyes: Soldiers photographs 1939-42," History of Photography 23, no. 4 (1999), 320.

${ }^{104}$ Sontag, On photography, 14-15.

${ }^{105}$ Hüppauf, Emptying the Gaze, 30.

${ }^{106}$ Ibid., 27. 
more a direct form of perpetration. Here, capturing the moment is intertwined with the process of dehumanization and was often staged with strong symbolical aspects and rituals, such as cutting beards or Payot (long curling sidelocks). The abusive act is a staged group performance showing dominance. Just as cut sidelocks, ears or other body parts can be seen as war trophies, ${ }^{107}$ this new visual technology capturing these symbols of power on film, could incorporate similar functions as a talisman or a trophy. Such visual symbols are also to be seen as social signs and honest signals. ${ }^{108}$ They show the affirmation and commitment to a "just cause"109 and their connectedness with the inner group of the soldiers' community. ${ }^{110}$ Janina Struk stated that "publicly to humiliate, degrade and possibly kill the 'real' Jew was metaphorically to destroy the image of the mythical Jew. Taking photographs was an integral part of the humiliation process, in the sense it completed the violation." ${ }^{\prime 11}$ Gerhard Paul also verified that this kind of photography and filming could be seen as acts of perpetration. ${ }^{12}$ The photographers and cameramen are getting involved in the act, placing themselves in and contributing to the abusive situation, then and afterwards. After all, the captured moment can be reproduced, shown and shared with others. It was a social and centrifugal practice that was widespread within the war and camp zones. Daniel Goldhagen described in Hitler's Willing Executioners how photographs taken by the members of the German Police Battalion 101 were "generously shared among the entire battalion." 113 The photographs were publicly displayed on the wall of barracks so that colleagues could order copies of them. Kurt Wafner, a member of the territorial defense battalion in Minsk, testified that himself made none of the atrocity photos in his personal album. He exchanged these photos "usually for a little tobacco."114 Even though we can agree that capturing these atrocities can be seen as a part of the perpetration process by shaping a visual framework of reference, it does not immediately confirm the statement that they were motivated by an exclusively "German eliminationist attitude"115 or "psycho-pathological mentality." 116 Although ideology and the general anti-Semitism played a tremendous role, the motives for taking pictures will be much more diverse, layered and complex.

\section{Motives of Perpetrator Photography}

Next to commissioned Nazi photography and filming, there was a ban on capturing atrocities during battle or in the camps. The Nazi high command, by means of the Chief of Staff of the $11^{\text {th }}$ Army, Otto Wöhler, clearly forbade such photographs that could undermine "the decency and discipline" of his soldiers:

It goes without saying for any normal human being, that no photographs will be made of such abominable excesses, and no report of them will be given in letters home. The production and distribution of such photographs and reports on such incidents are looked upon as undermining the decency and discipline into armed forces and will be severely punished. All existing photographs and reports on such excesses are to be confiscated together with the negatives and are to be sent to the Ic/ counter intelligence officer of the army giving the

\footnotetext{
${ }^{107}$ Hilary Roberts, “War Trophy Photographs: Proof or Pornography," in Picturing atrocity: photography in crisis, ed. Geoffrey Batchen et al. (London: Reaktion Books, 2014), 202.

${ }^{108}$ Amotz Zahavi and Avishag Zahavi, The Handicap Principle: A Missing Piece of Darwins Puzzle (New York: Oxford University Press, 1997), 218.

${ }^{109}$ Roberts, War Trophy Photographs, 202.

${ }^{110}$ Thomas Kühne, "The Pleasure of Terror: Belonging through Genocide," in Pleasure and Power in Nazi Germany, eds. Pamela E. Swett et al. (New York: Palgrave Macmillan, 2011), 237.

${ }^{111}$ Struk, Photographing the Holocaust, 63-64.

${ }_{112}$ Paul, Gerhard, BilderMACHT. Studien zur visual history des 20. und 21. Jahrhunderts (Göttingen: Wallstein-Verlag, 2013), $162,175-177$.

${ }^{113}$ Daniel Jonah Goldhagen, Hitler's Willing Executioners: Ordinary Germans and the Holocaust (New York: Vintage Books, 1997), 246.

${ }^{114}$ Struk, Photographing the Holocaust, 68.

${ }^{115}$ Goldhagen, Hitler's Willing Executioners, 247.

${ }^{116}$ Rossino, Eastern Europe through German Eyes, 314.
} 
name of the producer or distributor. It is beneath the dignity of a German soldier to watch such incidents out of curiosity. ${ }^{117}$

On November 11, 1941 and April 16, 1942, Reinhard Heydrich, the head of the Reichssicherheitshauptamt (Reich Security Head Office) reiterated the order of Woehler. ${ }^{118}$ It was explicitly forbidden to capture mass executions and asked that the commanders of the Order Police would trace and confiscate pictures and films that circulated among the men. In a well-described case, the SS-Untersturmführer Max Taubner was even sentenced to ten years of imprisonment for disobedience. ${ }^{119}$ In his verdict from the military court on May 24, 1943, we learned that he took a number of photographs, knowing that this was forbidden, "which showed the most deplorable excess, many are shameless and utterly revolting." 120 Taubner had the pictures developed in two photo shops in southern Germany and had showed them to his wife and friends. The SS court feared that "such pictures could pose the gravest risks to the security of the Reich if they fell into wrong hands," 121 and could be used for enemy propaganda. However, Taubner was clearly disobedient. When reading the minutiae of the verdict, one must conclude that his sensation-seeking behavior and his widely discussed enjoyment for tormenting Jewish victims, combined with an attempted abortion with his wife, made this a symbolical case that the SS court saw as "the expression of an inferior character."122 He was sentenced to ten years without the possibility to deduct the time already served. On November 3, 1943, Heinrich Himmler gave the order to burn the 69 photos and to destroy the negatives. ${ }^{123}$ In January 1945, Himmler finally pardoned Taubner after serving less than two years.

Despite the several military orders and court cases that clearly forbade capturing these atrocities, there was a massive production and dissemination of atrocity imagery. ${ }^{124}$ One can wonder what motivated and attracted so many soldiers to decisively disobey this Bilderverbot (picture ban) of violent excesses. ${ }^{125}$ In recent literature regarding perpetrator photography, a variety of reasons and motives are formulated. ${ }^{126}$ They are often single causal explanations that are framed within a paradigmatic view on the phenomenon. My proposition is that a diverse number of situational and dispositional motives are at play and that these motives interact with each other and the social situation (interplay) as well as affect further forms of perpetration within the system (circularity). The main motivational forces, in my opinion, are the following non-limitative functional elements:

\section{Nazi-ideology and Anti-Semitism}

Almost all authors acknowledge the significant role that Nazi ideology has played in shaping the polarized and xenophobic framework of reference. The totalitarian control and coordination of the media incrementally shaped a worldview that divided Us from Them, so-called Übermensch from Untermensch or the Superior from the Inferior. A large number of sources have indicated that many perpetrators incorporated feelings of racial superiority and uniqueness. They testified through their imagery and in their letters to the home front on the inhumane character and living conditions of conquered people such as Jews, Slavs, Roma and Sinti, Russians and other enemies. ${ }^{127}$ Their imagery both confirmed and contributed to the Manichean world they lived in. A visual framework that engaged some in the direct and willing participation to create the German

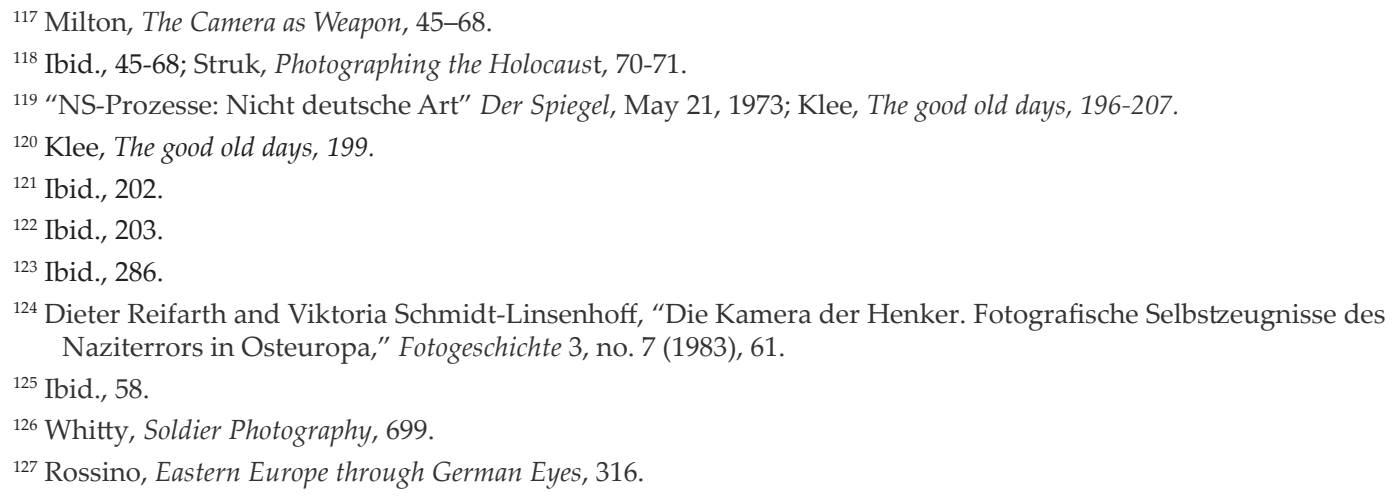


Volksgemeinschaft, just like the pharmacist in Norden who presented the Rassenschande photo in his shop window. ${ }^{128}$

\section{Neutralization and Distancing}

Another possible motive for capturing violent excesses is the nature of the subject itself. Often the scenes photographed showed extreme brutal and abusive behavior towards the victims, as can be witnessed in the photo series of the garage massacre in Kovno. For many soldiers, this was their first encounter with such gruesome atrocities. Andèn-Papadopoulos stated that capturing this violence could function "simultaneously to authenticate and filter a hurtful reality where death or serious injury is an all too real possibility." 129 In the same line, Petra Bopp questioned what exactly happens when we photograph the unimaginable. ${ }^{130}$ She reflected on the emotional distance by inserting a camera between the observer and the event that is observed. This technological device has a neutralizing effect on the other senses such as smell, hearing and feeling. The camera as such is objectifying the perception of what can be seen. The viewing process is seen as a pure optical process and is thereby separated from emotional feelings like empathy and compassion, an effect she also calls the "cold eye."131 In addition, Hüppauf mentioned that photography of that period is marked with an amorality and absence of resistance, which he called a perspective of neutralization and de-subjectification: "They presuppose an eye no longer clearly connected to the ' $\mathrm{I}$ ' of the photographer, but in search for a gaze that comes from a timeless and spaceless nowhere." 132 This way, the "I" can have the illusion of being present but not involved or engaged in the situation. Indeed, this "unusual degree of documentary neutrality"133 can be interpreted as an objectification through the camera lens and is a completely different type of motivation from the ideological willingness as described above.

\section{Social Dominance and Control}

Collective violence can also be visualized through photography or film with the purpose to reinforce a notion of superiority or a dominant position. Atrocities that degrade, dehumanize or humiliate a person or group are mostly the relational output of an extreme power imbalance. ${ }^{134}$ Capturing scenes of abuse and mass murder confirms and strengthens the absolute position, and also stimulates submission by the victim group. It controls and freezes the situation for the victims and triggers further victimization processes. ${ }^{135}$ When analyzing the photographs of the garage massacre in Kovno, we notice that the victim group is paralyzed by the abuse, the openness of the atrocities and the enthusiastic reactions by the bystanders. The fact that the Germans or other locals were not intervening but photographing the entire event psychologically limited the behavioral options for the victims. In such extreme situations, victim groups shrink and cling together, which in this case resulted in one person at a time stepping forward when called, knowing that he would be brutally killed with a blow from an iron crowbar.

\section{Torture and Fear Inducement}

From an even more instrumental perspective, photography can also be used as a specific instrument of torture. Photographing ritualized torture practices, that often include nudity, is not directed towards the destruction of the body per se but rather focused on destroying the personal identity

\footnotetext{
${ }^{128}$ Wildt, Picturing Exclusion, 139.

${ }^{129}$ Karin Andén-Papadopoulos, “Body horror on the Internet: US soldiers recording the war in Iraq and Afghanistan," Media, Culture \& Society 31, no. 6 (2009) 922.

${ }^{130}$ Bopp, Images of Violence, 187

${ }^{131}$ Ibid., 187; Reifarth, Die Kamera der Henker, 66.

${ }^{132}$ Hüppauf, Emptying the Gaze, 30.

${ }^{133}$ Ibid., 36.

${ }^{134}$ Martschukat, Violence and Visibility, 5.

${ }^{135}$ Jeffrey H. Goldstein, "Why we watch," in Why we watch: the attractions of violent entertainment, ed. Jeffrey H. Goldstein (New York: Oxford University Press, 2011), 222.
} 
and psychological well being. ${ }^{136}$ In this light, a camera can be seen as an additional instrument to induce fear and break down the mental health of the targeted subject. Furthermore, the threat of using and disseminating the imagery can be seen as a prolonged form of perpetration. Although I have not discussed any cases of torture by camera during the Holocaust, the manifold pictures taken by U.S. soldiers at the Abu Ghraib prison in Iraq are clear examples of this kind of practice.

Curiosity, Sensation Seeking and Sadistic Impulses

Another often cited motive for perpetrator photography is what I would call the continuum of curiosity, sensation seeking and sadistic impulses. ${ }^{137}$ Atrocities, abusive situations and death can trigger curiosity. Such attractions and death-defying behaviors are also observed in other species. ${ }^{138}$ This curiosity towards death and violence can have different gradations from a normal level to a morbid curiosity, ranging from enjoyment for risk and sensation-seeking behavior to sadistic impulses. Here, the actor no longer observes out of curiosity but actively triggers a situation for the satisfaction of his sadism. The origin of this curiosity and sensation seeking can, according to some researchers, be explained as an outcome of the civilization process as described by Norbert Elias. This behavior could be "a way to fill the void left by diminished opportunities to experience the real thing." 139 Likewise, Vicky Goldberg suggested that in our Western world, death is more and more excluded from our everyday lives. ${ }^{140}$ Where we used to see public executions on the market square as a form of deterrence and popular entertainment, we have placed these executions behind the prison walls to be no longer public. Since the late $18^{\text {th }}$ century, we have undergone a gradual and imperceptible reduction of death and dying. Convergent social, religious and medical changes have resulted in the near exclusion of death-related processes in larger society. Goldberg noticed that this process more or less coincided with our visual interest in imagery of death, e.g. the post mortem photography that was widely accepted until the Second World War. ${ }^{141}$ The same type of atrocity imagery can find its origin in the normal curiosity we all have towards these extreme situations as it can also function as trophies to triumphantly satisfy sadistic impulses. For me, this is the same kind of motivation but with a different level of gradation.

\section{Mood Management and Emotional Expressions}

Photography can also be motivated by the need to express emotions in ways that are most of the time prohibited or socially not accepted. ${ }^{142}$ It is clear that soldiers during their war efforts experienced intense emotions and feelings. The fear and stress over death (negative emotions) can be intertwined with feelings of euphoria and joy (positive emotions). ${ }^{143}$ Soldiers have repeatedly testified that during the war, they never felt so alive, being continuously confronted with death. War triggers intense emotions, and soldiers are in need of social and psychological means to cope with them. Photography can have a neutralizing and distancing effect, as described above, but it can also be used as a tool to overcome the social pressures in mood management within mainly male groups. Many of these soldiers had limited experiences in emotionally expressing these situations about which they were insecure and searched for socially accepted ways of understanding and reflecting upon these atrocities. A general pattern within male groups is socially objectifying the

\footnotetext{
${ }^{136}$ Paul, Gerhard. Der Bilderkrieg: Inszenierungen, Bilder und Perspektiven der "Operation Irakische Freiheit” (Göttingen: Wallstein-Verl., 2005), 192-195.

${ }^{137}$ Goldstein, Why we watch, 217; Dolf Zillmann, "The Psychology of the Appeal of Portrayals of Violence," in Why We Watch: The Attractions of Violent Entertainment, ed. Jeffrey H. Goldstein (New York: Oxford University Press, 2011$), 199$. 
emotional arousal or traumatic experience ${ }^{144}$ Capturing and sharing atrocity imagery can socially regulate these emotions and traumas.

Justice Motives and Revenge

Dolf Zillmann stated that “one person's joy is another's pain and one person's pain is another's joy." 145 Feelings of injustice can be strong motivators for violence and the ritualistic portrayal of it. ${ }^{146}$ Atrocities that were previously committed by the targeted victim group or those that were labeled to be responsible for the atrocities, can trigger feelings of hatred that need to be retributed. Such strong negative attitudes towards the victims as alleged former perpetrators can invoke "counter-empathy"147 and set the stage for revenge killings and often contribute to the enjoyment of the degradation and humiliation. ${ }^{148}$ It is a form of punitive violence that is considered to be morally right and fully deserved. As stated earlier, this justice motive was probably also one of the factors that influenced "the death dealer of Kovno." He revenged the murder of his parents and other nationals by the retreating Soviet NKVD (secret police). It is important to emphasize that these were relative feelings of injustice towards the victim group. The Jewish residents that were murdered by the Lithuanian auxiliaries were not responsible for the past atrocities by the NKVD, but they were considered to be indirectly responsible. Targeted groups such as the Jews were often linked with other enemies like the Bolsheviks. The irony is that most victims of collective violence were seen as a threat that needed to be eliminated or as perpetrators of former atrocities that had to be revenged. Needless to say, victims of genocidal violence were rarely a threat or related to former atrocities, but the mere notion was sufficient. ${ }^{149}$

\section{Peer Group Binding and Camaraderie}

Oskar Gröning, the Auschwitz bookkeeper who was recently sentenced to four years as an accessory to murder in 300,000 cases, testified earlier that leaving Auschwitz was difficult due to the friendships he made there. He stated that "the special situation at Auschwitz led to friendships which, I still today, I think back on with joy." 150 Much of the photography seemed to be produced as a result of camaraderie or male bonding. It created a group identity and established the boundaries of the military community and their core values of honor, obedience and connectedness. ${ }^{151}$ This is what can be seen on the team-building photos of the Auschwitz staff at the Solahütte. Pierre Bourdieu reflected on this matter as follows: "If one accepts, with Durkheim, that the function of the festivity is to revitalize and recreate the group, one will understand why the photograph is associated with it, since it supplies the means of solemnizing those climatic moments of social life in which the group solemnly reaffirms its unity." 152 The image has binding qualities, both for the perpetrator and victim group. Michael Wildt noticed also that acts of humiliation, and photographing them, are predominantly organized by men. ${ }^{153}$ There seems to be a gender-specific reinforcement for men needing to prove themselves before their peers and to be considered as fearless in contrast with women who may demonstrate their sensitivity and their need to be caring. ${ }^{154}$ Such societal schemes highly influence the social roles and specific forms of (violent) group behavior.

\footnotetext{
${ }^{144}$ Zillmann, The Psychology of the Appeal of Portrayals of Violence, 196-199.

${ }^{145}$ Ibid., 202.

${ }^{146}$ Ibid., 203-204.

${ }^{147}$ Ibid., 202.

${ }^{148}$ Goldstein, Why We Watch, 220.

${ }^{149}$ Dawn L. Roth and David Kauzlarich, "A Victimology of State Crime," in Towards a Victimology of State Crime, eds. Dawn L. Roth and David Kauzlarich (London: Routledge, Taylor \& Francis Group, 2014$), 9$.

${ }^{150}$ Laurence Rees, Auschwitz: The Nazis and the Final Solution (London: BBC Books, 2005), 206.

${ }^{151}$ Andén-Papadopoulos, Body Horror on the Internet, 922; Goldstein, Why We Watch, 215-215.

${ }_{152}$ Pierre Bourdieu and Luc Boltanski, Photography: A Middle-Brow Art (Stanford, CA: Stanford University Press, 2005), 20-21.

${ }^{153}$ Wildt, Picturing Exclusion, 145.

${ }^{154}$ Zillmann, The Psychology of the Appeal, 197.
} 
Technological Motives and Cultural Shifts

In addition, technological advancements and cultural transitions can trigger new forms of visualizing atrocities. ${ }^{155}$ As the acts of public shaming on the market square were relatively limited in their reach before photography, they gradually reached wider audiences as the images of degradation could be captured, duplicated and printed in popular media. New technology, from steam-driven presses to the Internet, can broaden and decentralize these acts of perpetration. Often these technological advances are accompanied with cultural transitions and rapid social change. During the Nazi era, the further industrialization, the rise of capitalism and the expansion of tourism had their effects on the masses and the capturing of their complex societies and layered frameworks of reference. These accumulating and resonating visual discourses at that time are one of the early examples of the rapid transition towards a (visual) information-based society.

These are some major motives for photographing and filming atrocities committed during episodes of collective violence. Of course, this list is not limitative and can be enriched with additional motives as we gradually better understand the complexity and the reasons why people become engaged in perpetrator photography, in spite of official bans or social pressures. In contrast with other authors, I am not convinced that single causes can motivate such behavior. The complex interplay of a multitude of motives is more likely from a behavioral point of view. ${ }^{156} \mathrm{I}$ also want to stress the fact that these motivational causes do not work in a social or causal vacuum; one cause can affect another cause and another. The continuous social polarization within a society, as seen in National Socialism, ${ }^{157}$ can lead to the creation of more space, attraction or tolerance for sensation-seeking, sadistic behaviors and more positive attitudes towards violence. After all, people and their motives live and interact together. They are highly active and social elements that continually impart meanings to their situations. From this perspective, it is not only important to see photographing and filming as acts of perpetration ${ }^{158}$ but also to appreciate them as performative actions that will be interpreted and given several meanings by other possible perpetrators. In this way, the creation and dissemination of atrocity imagery has a circular effect and can lead to a downward spiral of further abusive and murderous actions.

\section{Photo and Film as Performatives}

According to Sontag, "photos echo photos." 159 As an example, she connected the photos of Bosnian prisoners in the Serbian camp of Omarska in 1992 with the Auschwitz imagery during the liberation of the camp in 1945. The Abu Ghraib photos, depicting the torture scenes of Iraqi prisoners by U.S. soldiers, were publicly presented on mural paintings in $\operatorname{Iran}^{160}$ and inspired terrorist groups such as ISIS to mirror the orange jumpsuits in their highly staged atrocity imagery. Photos and film capture a momentum and also become tools that can be used, that have an effect, that prompt for action, et cetera. Whatever the motivations were to capture them, we also need to analyze what these photographs and films do. It is certain that atrocity imagery will shape a certain reality and that it will affect and emotionally impact people. Paul Lowe and Peggy Phelan both emphasized the performative power of such imagery. Phelan used the analogy of performative speech, where saying something is the same as doing something, e.g. saying I do during a wedding ceremony. ${ }^{161}$ She described atrocity imagery as "theaters of humiliation."162 A photo can justify certain actions, can neutralize emotions and feelings, can inflame rage and can shock an individual, a group and even an entire society. This performative power of imagery was well understood during the National Socialist era. In 1933, just after the regime change, Dr Hans Traub wrote the booklet Der

${ }^{155}$ Goldstein, Why We Watch, 221.

${ }^{156}$ Zillmann, The Psychology of the Appeal, 209.

${ }_{157}$ Wildt, Picturing Exclusion, 142-144.

${ }^{158}$ Paul, BilderMACHT, 175-177.

${ }^{159}$ Susan Sontag, Regarding the Pain of Others (New York: Picador, 2010), 84.

${ }^{160}$ Paul, BilderMACHT, 615.

${ }^{161}$ Peggy Phelan, "Atrocity and Action: The Performative Force of the Abu Ghraib Photographs," in Picturing Atrocity: Photography in Crisis, ed. Geoffrey Batchen et al. (London: Reaktion Books, 2014), 52-53.

${ }^{162}$ Ibid., 55. 
Film als politisches Machtmittel (The Film as an Instrument of Power). Traub explained that film is the second most important medium in propaganda; the most important medium is, of course, the voice of the Führer. ${ }^{163}$ In analyzing film as a performative instrument, he also focused on movement and rhythm, which are both tools of propaganda and ideology, a language that Leni Riefenstahl mastered perfectly. Lowe argued that this is also the case for photography: "The photographs become an imaginatively performative space, in the multivalent senses of the performance: of taking the image, the choreography of the photographer, subject and environment; in terms of the production and dissemination of images in an ecology of meanings; and in terms of the invitation to the viewer to engage in a performative reading of the imaginative meanings of the image."164 Likewise, Sontag stated that (atrocity) photographs "lay down routes of reference, and serve as totems of causes." 165

The visual portrayal of acts of aggression (media violence) affects the viewer. Since the rise of popular media, there has been a keen interest in the effects of exposure to visual frames of violence. Since 1960, criminologists, pedagogues and psychologists researched extensively what the risks were for youth being exposed to such violence in television, movies, video games, the Internet, et cetera. ${ }^{166}$ In recent years, from a more neurobiological approach, one examines how such imagery effects brain processes and what the social effects could be. Of course, as Huesmann emphasized, "no reputable researcher is suggesting that media violence is 'the' cause of violent behavior." ${ }^{167} \mathrm{We}$ need to look at violent imagery from a developmental or transitional perspective, where atrocity imagery can impact-together with other causes that interplay-the demonic transition on the continuum of perpetration. ${ }^{168}$ In this light, it seems necessary to mention the main psychological theories on why and how visual frameworks of violence stimulates possible aggressive behavior of the viewer. Huesmann divided the effects of such exposure in the long and short term. ${ }^{169}$

The short-term effects include priming, arousal and mimicry. ${ }^{170}$ Priming can be seen as a process that by presenting a certain stimulus, a specific cognition, emotion or behavior is triggered. For example, seeing a gun can excite the cognition of aggression and stimulate fight or flight reactions. In our case, an ethnic group, such as the stereotypical portrayal of the mythical Jews, can become linked to certain degrading beliefs and emotions or behaviors connected to that. When some form of degrading imagery is implemented through mass media, it will possibly also arouse the observers through the mechanisms of excitation transfer ${ }^{171}$ (e.g. provocation that arouses anger) and generate a higher level of general arousal. This diminishes the inhibitions of inappropriate responses to certain events or groups and installs the dominant learned processes as socially accepted methods of representation or problem solving. An example of these short-term arousal effects is the Antwerp Kristallnacht on 14 April 1941. After the screening of the infuriating movie Der ewige Jude, two synagogues and several Jewish houses were destroyed by extreme rightwing groups. The screening of the movie angered the crowd and triggered an aggressive outburst that gradually grew within these extremist groups. ${ }^{172}$ Another social-psychological mechanism is mimicry or the imitation of specific behavior. Much of learning mechanisms are socially construed through observation and imitation. Humans and other primates have an innate tendency to mimic the thinking and acting in their environment. Mass movements that are visually reinforced, such as described above, only strengthen these mechanisms.

\footnotetext{
${ }^{163}$ Hans Traub, Der Film als politisches Machtmittel (München: Münchener Druck- und Verlagshaus, 1933), 28.

${ }^{164}$ Paul Lowe, "Picturing the Perpetrator," in Picturing atrocity: photography in crisis, ed. Geoffrey Batchen et al. (London: Reaktion Books, 2014), 198

${ }^{165}$ Sontag, Regarding the Pain of Others, 85.

${ }^{166}$ L. Rowell Huesmann, “The Impact of Electronic Media Violence: Scientific Theory and Research,” Journal of Adolescent Health 41, no. 6 (2007), 1.

167 Ibid., 2.

${ }^{168}$ Busch, Demonic Transitons, 52.

${ }^{169}$ Huesmann, The Impact of Electronic Media Violence, 3-4.

${ }^{170}$ Ibid., 3.

${ }^{171}$ Zillmann, The Psychology of the Appeal of Portrayals of Violence, 207.

${ }^{172}$ Lieven Saerens, De jodenjagers van de Vlaamse SS: gewone Vlamingen? (Tielt: Lannoo, 2008), 67-76.
} 
In the long term, the effects of exposure to visual violence are mainly observational learning, desensitization and enactive learning. ${ }^{173}$ Social behavior of a person is the result of the interplay between situational and dispositional elements. Besides situational dynamics such as conformity and obedience, the dispositional aspects include the emotional state, normative beliefs, frameworks of reference about the world and behavioral scripts that people have learned socially. ${ }^{174}$ These behavioral scripts are formed through observation of family, peers, colleagues, community members and mass media. If dehumanization and social exclusion are abundantly present and have become the social norm within a community, it is reasonably certain that this will influence behavioral scripts towards the targeted groups. The long-term effects of this kind of socialization will therefore lead to a process of desensitization. ${ }^{175}$ Multiple exposure to emotionally disturbing imagery can lead to habituation. The negative emotional feelings that are connected with the visual atrocities will decline after repeated and different forms of exposure. Huesmann suggested that people are "not just observers, but also active participants."176 This observational learning and systematic desensitization will interplay with other learning processes, such as enactive (actionbased) learning and mechanisms including conditioning, (self-)selection, recruitment, et cetera. ${ }^{177}$ Although the research and discussions on the effects of media violence are still highly debated, it has been increasingly accepted that exposure has a certain effect on the viewers. Seeing atrocity imagery is therefore not a direct cause of violence, but it influences the psychological processes that promote tolerance towards violence. ${ }^{178}$ In analyzing the photos and letters from German soldiers on the battlefield, Rossino indicated that the extensive ideological exposure in their private lives and the active indoctrination during their military training greatly impacted their consciousness. ${ }^{179}$

\section{Conclusion}

The multitude of motives for atrocity imagery, the circular effects it has and interplay of motives and effects result in a cumulative learning process that can build schemas that strongly divide the social reality in Us versus Them. ${ }^{180}$ Visual media in general and atrocity imagery in particular contribute tremendously to the process of "Otherization" or what Kathleen Taylor detailed as "an increasingly impassable social gulf between Us and Them". ${ }^{181}$ The Nazi regime invested highly in this visual process of otherization through photography and film, resulting in a broad acceptance of a Volkgemeinschaft (national community) that applied a different set of moral rules towards the in-group and the out-group. The performative power of photography and film had binding qualities that demarcated the boundaries between these groups. As performatives, the imagery bound the in-group (Us) in processes of perpetration and bound the out-group (Them) in processes of victimization. The two Auschwitz albums (Karl Höcker versus Lili Jacob) clearly visualized these parallel worlds. On the one side, you have the perpetrator reality expressing camaraderie, absolute dominance and superiority or Schöne Zeiten in summary, and on the other side, there was the reality of the victims that gradually became totally excluded from a moral world. Capturing and presenting the incremental stages of otherization through celluloid contributed to the intense bond of perpetration and victimization for each respective group separately. The intensifying investments by the Nazi society in creating and sharing a visual framework of reference affected the process of perpetration. However that perpetrator behavior is always the result of a complex interplay of many (f)actors, it is clear that the cumulative imagery of atrocities has affected gradually the

\footnotetext{
${ }^{173}$ Huesmann, The Impact of Electronic Media Violence, 4.

${ }^{174}$ L. Rowell Huesmann, "Psychological Processes Promoting the Relation Between Exposure to Media Violence and

Aggressive Behavior by the Viewer," Journal of Social Issues 42, no. 3 (1986), 130.

${ }^{175}$ Huesmann, The Impact of Electronic Media Violence, 4.

${ }^{176}$ Ibid., 4.

177 Ibid.

${ }^{178}$ Ibid., 6.

${ }^{179}$ Rossino, Eastern Europe through German Eyes, 315.

${ }^{180}$ Huesmann, Psychological Processes, 125.

${ }^{181}$ Kathleen E. Taylor, Cruelty: Human Evil and the Human Brain (Oxford: Oxford University Press, 2009), 8.
} 
broader society towards a more positive attitude in using violence against the targeted out-group. The camera as a crucial weapon for a divided world.

\section{Bibliography}

Andén-Papadopoulos, Karin. "Body horror on the Internet: US soldiers recording the war in Iraq and Afghanistan." Media, Culture \& Society 31, no. 6 (2009), 921-938. https://doi. org $/ 10.1177 / 0163443709344040$

"Augenzeugen der Pogrome auf dem Lietukis Garagenhof Kaunas 1941." History. Litauen (Fast) alles ueber Litauen! Accessed May 1, 2017. https://www.alles-ueber-litauen.de/litauengeschichte/lietukis-massaker-1941.html.

Batchen, Geoffrey, Mick Gidley, Nancy K. Miller, and Jay Prosser, eds. Picturing Atrocity: Photography in Crisis. London: Reaktion Books, 2014.

Berger, Sara. Experten der Vernichtung: das T4-Reinhardt-Netzwerk in den Lagern Belzec, Sobibor und Treblinka. Hamburg: Hamburger Edition, 2014.

Boeckl-Klamper, Elisabeth. "Pogrome in Kowno (Kaunas/Kauen), Juni 1941." Dokumentationsarchiv des österreichischen Widerstandes. Accessed May 1, 2017. https://www.doew.at/erinnern/ fotos-und-dokumente/1938-1945/pogrome-in-kowno-kaunas-kauen-juni-1941.

Bopp, Petra. "Images of Violence in Wehrmacht Soldiers' Private Photo Albums." In Violence and visibility in modern history, edited by Jürgen Matschukat and Silvan Niedermeier, 181-197. New York: Palgrave Macmillan, 2015.

Bourdieu, Pierre, and Luc Boltanski. Photography: A Middle-Brow art. Stanford: Stanford University Press, 2005.

Brasse, Wilhelm, and Maria Anna Potocka. Wilhelm Brasse, Fotograf, 3444, Auschwitz 1940-1945. Berlin: Revolver Publ. by VVV, 2011.

Brockhaus, Gudrun, ed. Attraktion der Nazibewegung. Essen: Klartext, 2014.

Browning, Christopher R. Ordinary men: Reserve Police Battalion 101 and the Final Solution in Poland. New York: HarperCollins Publishers, 1993.

Bucher, Peter. Wochenschauen und Dokumentarfilme 1895-1950 im Bundesarchiv-Filmarchiv. vol. 8. Koblenz: Bundesarchiv, 2000. Accessed May 1, 2017. https://www.bundesarchiv. de/imperia/md/content/bundesarchiv de/recherche/findbuch wochenschauen dokumentarfilme.pdf.

Busch, Christophe. "Demonic Transitons: How Ordinary People Can Commit Extraordinary Evil." In Genocide: New Perspectives on its Causes, Courses and Consequences, edited by Üngör Ugur Ümit, 49-82. Amsterdam: Amsterdam University Press, 2016.

. "Kar-Friedrich Gottlieb Höcker, der Adjutant von Lublin und Auschwitz." In Das HöckerAlbum Auschwitz durch die Linse der SS, edited by Christophe Busch, Stefan Hördler, and Robert Jan van Pelt, 36-71. Darmstadt: Von Zabern, 2016.

Busch, Christophe, Stefan Hördler, and Robert Jan van Pelt, eds. Das Höcker-Album: Auschwitz durch die Linse der SS. Darmstadt: Von Zabern, 2016.

Chéroux, Clément. Mémoire des camps: Photographies des camps de concentration et dextermination nazis (1933-1999). Paris: Marval, 2001.

Der Reichsführer SS. Der Untermensch. Berlin: Nordland-Verlag GMBH, 1942.

Dietrich, Hans. "Bericht des NSDAP-Reichstagsabgeordneten." Coburger Zeitung, June 28, 1933.

Eckert, Gerhard. Der Rundfunk als Führungsmittel, vol. 1. Studien zum Weltrundfunk und Fernsehrundfunk. Heidelberg: K. Vowinckel, 1941.

Frei, Norbert, Thomas Grotum, Jan Parcer, Sybille Steinbacher, and Bernd C. Wagner. Standort- und Kommandanturbefehle des Konzentrationslagers Auschwitz 1940-1945. München: K. G. Saur, 2000.

Goebbels, Joseph. Das eherne Herz. Reden und Aufsätze. München: Zentralverlag der NSDAP, 1942.

Goldhagen, Daniel Jonah. Hitler's Willing Executioners: Ordinary Germans and the Holocaust. New York: Vintage Books, 1997.

Goldstein, Jeffrey H., ed. Why We Watch: The Attractions of Violent Entertainment. New York: Oxford University Press, 2011. 
Goldberg, Vicki. "Death Takes a Holiday, Sort Of." In Why We Watch: The Attractions of Violent Entertainment, edited by Jeffrey H. Goldstein, 27-52. New York: Oxford University Press, 2011.

Goldstein, Jeffrey H. "Why We Watch." In Why We Watch: The Attractions of Violent Entertainment, edited by Jeffrey H. Goldstein, 212-226. New York: Oxford University Press, 2011.

Gutman, Israel, and Belah Guterman. The Auschwitz album: The Story of a Transport. Jerusalem: Yad Vashem, 2008.

Hartman, Geoffrey H. Holocaust Remembrance: The Shapes of Memory. Oxford: Blackwell, 1995.

Harvey, Elizabeth. "Seeing the World: Photography, Photojournalism and Visual Pleasure in the Third Reich." In Pleasure and Power in Nazi Germany, edited by Pamela E. Swett, Corey Ross, and Fabrice d'Almeida, 177-204. New York: Palgrave Macmillan, 2011.

Hitler, Adolf. Mein Kampf, 2nd ed. Stockholm: White Wolf, 2015.

Hoffmann-Curtius, Kathrin. "Trophäen in Brief-Taschen - Fotos von Wehrmachts-, SS- und PolizeiVerbrechen." Kunsttexte.de, no. 3 (2002), 1-14.

Holocaust Education \& Archive Research Team. "The Massacres in Kovno Reports and Eyewitness Accounts." Accessed May 1, 2017. http://www.holocaustresearchproject.org/einsatz/ kovnomassacres.html.

Huesmann, L. Rowell. "Psychological Processes Promoting the Relation Between Exposure to Media Violence and Aggressive Behavior by the Viewer." Journal of Social Issues 42, no. 3 (1986), 125-139.

"The Impact of Electronic Media Violence: Scientific Theory and Research." Journal of Adolescent Health 41, no. 6 (2007), 1-11.

Hüppauf, Bernd. "Emptying the Gaze: Framing Violence through the Viewfinder." New German Critique, no. 72 (1997), 3-44.

---------. "Foltern mit der Kamera. Was zeigen Fotos aus dem Irakkrieg?" Fotogeschichte24, no. 93 (September 2004), 51-59.

Kanitzberg, C.A. “Der neue Weg." Photofreund 1933, no. 13 (July 29, 1933), 259-260.

Kershaw, Ian. "'Working towards the Führer': reflections on the nature of the Hitler dictatorship." In Stalinism and Nazism: Dictatorships in Comparison, edited by Ian Kershaw and Lewin Moshe, 88-106. Cambridge: Cambridge University Press, 2005.

Kershaw, Ian, and Moshe Lewin. Stalinism and Nazism: Dictatorships in Comparison. Cambridge: Cambridge University Press, 2005.

Klee, Ernst, Willi Dressen, and Volker Rieß. The good old days: the Holocaust as seen by its perpetrators and bystanders. Old Saybrook: Konecky \& Konecky, 2005.

Knigge, Volkhard, Lüttgenau Rikola-Gunnar, and Jens-Christian Wagner. Forced labor: the Germans, the forced laborers, and the war: companion volume to the exhibition. Weimar: Buchenwald and Mittelbau-Dora Memorials Foundation, 2010.

Knightley, Phillip. The first casualty: the war correspondent as hero and myth-Maker from the Crimea to Iraq. Baltimore: Johns Hopkins University Press, 2004.

Knoch, Habbo. "Die 'Volksgemeinschaft' der Bilder: Propaganda und Geselschaft im frühen Nationalsozialismus." In Attraktion der Nazibewegung, edited by Gudrun Brockhaus. Essen: Klartext, 2014.

Kühne, Thomas. "The Pleasure of Terror: Belonging through Genocide." In Pleasure and Power in Nazi Germany, edited by Pamela E. Swett, Corey Ross, and Fabrice d'Almeida, 234-255. New York: Palgrave Macmillan, 2011.

Laimonas, Noreika. "Oral history interview with Laimonas Noreika." United States Holocaust Memorial Museum. RG-50.473*0096. Accessed June 1, 2017. https://collections.ushmm.org/ search/catalog/irn518271.

Levin, Judith, and Daniel Uziel. "“'Ordinary Men, Extraordinary Photos.” Yad Vashem Studies 26 (1998), 265-279.

Linfield, Susie. The cruel radiance: photography and political violence. Chicago: University of Chicago, 2012. 
Lowe, Paul. "Picturing the Perpetrator." In Picturing atrocity: photography in crisis, edited by Geoffrey Batchen, Mick Gidley, Nancy K. Miller, and Jay Prosser, 189-200. London: Reaktion Books, 2014.

Mallmann, Klaus-Michael, and Gerhard Paul, eds. Karrieren der Gewalt: Nationalsozialistische Täterbiographien. Darmstadt: Primus, 2013.

Martschukat, Jürgen, and Silvan Niedermeier. "Violence and Visibility: Historical and Theoretical Perspectives." In Violence and visibility in modern history, edited by Jürgen Martschukat and Silvan Niedermeier, 1-23. New York: Palgrave Macmillan, 2015.

Milton, Sybil. "The Camera as Weapon: Documentary Photography and the Holocaust." Simon Wiesenthal Center Annual no. 1 (1984), 45-68. Accessed May 1, 2017. http://motlc.wiesenthal. com/site/pp.asp?b=394975\&c=gvKVLcMVIuG.

Mommsen, Hans. "Cumulative radicalisation and progressive self-Destruction as structural determinants of the Nazi dictatorship." In Stalinism and Nazism: dictatorships in comparison, edited by Ian Kershaw and Lewin Moshe, 75-87. Cambridge: Cambridge University Press, 2005.

Mönch, Regina. "Foto-Ausstellung: Das Album des Mörders." FAZ.NET, September 11, 2006. Accessed May 1, 2017. http://www.faz.net/aktuell/feuilleton/debatten/foto-ausstellungdas-album-des-moerders-1355986.html.

“NS-Prozesse: Nicht deutsche Art." Der Spiegel, May 21, 1973.

Paul, Gerhard. Aufstand der Bilder: die NS-Propaganda vor 1933. Bonn: Dietz, 1992.

. Der Bilderkrieg: Inszenierungen, Bilder und Perspektiven der "Operation Irakische Freiheit. Göttingen: Wallstein, 2005.

. BilderMACHT. Studien zur visual history des 20. und 21. Jahrhunderts. Göttingen: Wallstein, 2013.

Pflug, Gabriele, ed. Das sichtbare Unfassbare: Fotografien vom Konzentrationslager Mauthausen: Katalog zur gleichnamigen Ausstellung = The visible part: photographs of Mauthausen Concentration Camp. Wien: Mandelbaum Verlag, 2005.

Phelan, Peggy. "Atrocity and Action: The Performative Force of the Abu Ghraib Photographs." In Picturing atrocity: photography in crisis, edited by Geoffrey Batchen, Mick Gidley, Nancy K. Miller, and Jay Prosser, 51-61. London: Reaktion Books, 2014.

Prosser, Jay. "Introduction." In Picturing atrocity: photography in crisis, edited by Geoffrey Batchen, Mick Gidley, Nancy K. Miller, and Jay Prosser, 7-13. London: Reaktion Books, 2014.

Rees, Laurence. Auschwitz: the Nazis and the final solution. London: BBC Books, 2005.

Reifarth, Dieter, and Viktoria Schmidt-Linsenhoff. "Die Kamera der Henker. Fotografische Selbstzeugnisse des Naziterrors in Osteuropa." Fotogeschichte 3, no. 7 (1983), 57-71. Accessed May 1, 2017. http://www.zeithistorische-forschungen.de/reprint/id=5255.

Rieß, Volker. "20 Jahre nach 'Schöne Zeiten.' Ein kritischer Rückblick mit Bildern." Mitteilungen aus dem Bundesarchiv, 2008. Accessed May 1, 2017. https://www.bundesarchiv.de/ fachinformationen/01816/index.html.de.

Ritchin, Fred. "Toward a Hyperphotography." In Picturing atrocity: photography in crisis, edited by Geoffrey Batchen, Mick Gidley, Nancy K. Miller, and Jay Prosser, 261-271. London: Reaktion Books, 2014.

Roberts, Hilary, Geoffrey Batchen, Mick Gidley, Nancy K. Miller, and Jay Prosser. "War Trophy Photographs: Proof or Pornography." In Picturing atrocity: photography in crisis, 201-208. London: Reaktion Books, 2014.

Ross, Corey, and Fabrice d'Almeida. "Radio, Film and Morale: Wartime Entertainment between Mobilization and Distraction." In Pleasure and Power in Nazi Germany, edited by Pamela E. Swett and Corey Ross, 154-174. New York: Palgrave Macmillan, 2011.

Rossino, Alexander B. "Eastern Europe through German eyes: Soldiers photographs 193942." History of Photography 23, no. 4 (1999), 313-321.

Roth, Dawn L., and David Kauzlarich. "A Victimology of State Crime." In Towards a Victimology of State Crime, edited by Dawn L. Roth and David Kauzlarich, 3-14. London: Routledge, Taylor \& Francis Group, 2014. 
Rothe, Dawn, and David Kauzlarich, eds. Towards a victimology of state crime. London: Routledge, Taylor \& Francis Group, 2014.

Sachsse, Rolf. “'Es wird nochmals ausdrücklichst darauf hingewiesen...' Aspekte der Bildzensur im NS-Staat und im Zweiten Weltkrieg." In Fotografieren verboten! Heimliche Aufnahmen von der Zerstörung Kölns, edited by Thomas Deres and Martin Rüther, 11-62. Köln: Emons, 1995.

Saerens, Lieven. De jodenjagers van de Vlaamse SS: gewone Vlamingen? Tielt: Lannoo, 2008.

Schäfer, Werner. Konzentrationslager Oranienburg. Das Anti-Braunbuch über das erste deutsche Konzentrationslager. Berlin: Buch u. Tiefdruckgeselschaft m.b.h., Abt. Buchverlag, 1934.

Seger, Gerhart. Oranienburg: erster authentischer Bericht eines aus dem Konzentrationslager Geflüchteten. Karlsbad: Verlagsanstalt Graphia, 1934.

Segev, Tom. Soldiers of evil: the commandants of the Nazi concentration camps. New York: McGrawHill, 1988.

Setkiewicz, Piotr. "Außenkommando SS-Hütte Solatal." In Das Höcker-Album Auschwitz durch die Linse der SS, edited by Christophe Busch, Stefan Hördler, and Robert Jan van Pelt, 160-171. Darmstadt: Von Zabern, 2016.

-------. The private lives of the Auschwitz SS. Oświęcim: Auschwitz-Birkenau State Museum, 2014.

Sontag, Susan. On photography. New York: Picador, 2010.

---.-. Regarding the pain of others. New York: Picador, 2010.

Starke, Sandra. "Papi macht Witzchen' SS-Soldaten als Knipser." Lecture, June 6, 2008. Medienamateure: Wie verändern Laien unsere visuelle Kultur.

Stiftung Brandenburgische Gedenkstätten. “VI. Wie Ebert, Heilmann und die Leiter des Rundfunks eingeliefert wurden." Die politischen Häftlingen des Konzentrationslager Oranienburg. Accessed May 1, 2017. http://www.stiftung-bg.de/kz-oranienburg/index.php?id=37.

Stiftung Gedenkstätten Buchenwald und Mittelbau-Dora. "Fotos: Radikalisierung. Zwangsarbeit im besetzten Europa." Ausstellung Zwangsarbeit - Presseinformation. Accessed May 1, 2017. http://www.ausstellung-zwangsarbeit.org/aktuelles/presseinformation/?L=0.

Struk, Janina. Photographing the Holocaust: interpretations of the evidence. London: I.B. Tauris, 2011.

Swett, Pamela E., Corey Ross, and Fabrice d'Almeida, eds. Pleasure and power in nazi germany. New York: Palgrave Macmillan, 2014.

Taylor, Kathleen E. Cruelty: Human evil and the human brain. Oxford: Oxford University Press, 2009.

The International School for Holocaust Studies. "The Eastern Front: Photographs as Propaganda." Accessed May 1, 2017. http://www.yadvashem.org/yv/en/education/newsletter/29/ photographs propaganda.asp.

Traub, Hans. Der Film als politisches Machtmittel. München: Münchener Druck- und Verlagshaus, 1933.

Üngör, Ugur Ümit, ed. Genocide: New perspectives on its causes, courses and consequences. Amsterdam: Amsterdam University Press, 2016.

White, Thomas, Susan Crane, and Andreas Weinhold. "Dehumanization and Incitement: The Use and Abuse of Holocaust Photographs and Images." Cohen Center for Holocaust and Genocide Studies. Handout. Accessed May 1, 2017. http://www.keene.edu/academics/ah/ cchgs/resources/educational-handouts/decoding-images/download/.

Whitty, Noel. "Soldier Photography of Detainee Abuse in Iraq: Digital Technology, Human Rights and the Death of Baha Mousa." Human Rights Law Review 10, no. 4 (2010), 689-714.

Wildt, Michael. "Die Epochenzäsur 1989/90 und die NS-Historiographie." Zeithistorische Forschungen/Studies in Contemporary History, no. 5 (2008), 349-371. Accessed May 1, 2017. http://www.zeithistorische-forschungen.de/3-2008/id=4757.

Wildt, Michael. "Picturing Exclusion: Race, Honor, and Anti-Semitic Violence in Nazi Germany before the Second World War." In Violence and visibility in modern history, edited by Jürgen Martschukat and Silvan Niedermeier, 137-155. New York: Palgrave Macmillan, 2015.

Zahavi, Amotz, and Avishag Zahavi. The handicap principle: a missing piece of Darwins puzzle. New York: Oxford University Press, 1997.

Zillmann, Dolf. "The Psychology of the Appeal of Portrayals of Violence." In Why we watch: the attractions of violent entertainment, edited by Jeffrey H. Goldstein, 179-211. New York: Oxford University Press, 2011. 